Article

\title{
Impact of Climate Change on Daily Streamflow and Its Extreme Values in Pacific Island Watersheds
}

\author{
Olkeba Tolessa Leta ${ }^{1, *(\mathbb{D})}$, Aly I. El-Kadi ${ }^{1,2}$ and Henrietta Dulai ${ }^{2}$ \\ 1 Water Resources Research Center, University of Hawaii at Manoa, Honolulu, HI 96822, USA; \\ elkadi@hawaii.edu \\ 2 Department of Geology and Geophysics, University of Hawaii at Manoa, Honolulu, HI 96822, USA; \\ hdulaiov@hawaii.edu \\ * Correspondence: otleta@hawaii.edu; Tel.: +1-808-956-6331
}

Received: 14 May 2018; Accepted: 13 June 2018; Published: 17 June 2018

check for updates

\begin{abstract}
The integration of hydrology and climate is important for understanding the present and future impact of climate on streamflow, which may cause frequent flooding, droughts, and shortage of water supply. In view of this, we assessed the impact of climate change on daily streamflow duration curves as well as extreme peak and low flow values. The objectives were to assess how climate change impacts watershed-wide streamflow and its extreme values and to provide an overview of the impacts of different climate change scenarios (Representative Concentration Pathways (RCP) 4.5 and 8.5) on streamflow and hydrological extremes when compared with the baseline values. We used the Soil and Water Assessment Tool (SWAT) model for daily streamflow and its extreme value modeling of two watersheds located on the Island of Oahu (Hawaii). Following successful calibration and validation of SWAT at three USGS flow gauging stations, we simulated the impact of climate change by the 2050s (2041-2070) and the 2080s (2071-2100). We used climate change perturbation factors and applied the factors to the historical time series data of 1980-2014. SWAT adequately reproduced observed daily streamflow with Nash-Sutcliffe Efficiency (NSE) values of greater than 0.5 and bracketed $>80 \%$ of observed streamflow data at $95 \%$ model prediction uncertainty at all flow gauging stations, indicating the applicability of the model for future daily streamflow prediction. We found that while the considered climate change scenarios generally show considerable negative impacts on daily streamflow and its extreme values, the extreme peak flows are expected to increase by as much as $22 \%$ especially under the RCP 8.5 scenario. However, a consistent decrease in extreme low flows by as much as $60 \%$ compared to the baseline values is projected. Larger negative changes of low flows are expected in the upstream part of the watersheds where higher groundwater contributions are expected. Consequently, severe problems, such as frequent hydrological droughts (groundwater scarcity), reduction in agricultural crop productivity, and increase in drinking water demand, are significantly expected on Oahu. Furthermore, the extreme values are more sensitive to rainfall change in comparison to temperature and solar radiation changes. Overall, findings generally indicated that climate change impacts will be amplified by the end of this century and may cause earlier occurrence of hydrological droughts when compared to the current hydrological regime, suggesting water resources managers, ecosystem conservationists, and ecologists to implement mitigation measures to climate change in Hawaii and similar Islands.
\end{abstract}

Keywords: climate change; extreme streamflow; Hawaii; streamflow; SWAT

\section{Introduction}

Ever-increasing industrialization and population growth have been putting considerable pressure on the environment and freshwater resources. Globally, the consistent increase in greenhouse gas 
emissions, such as carbon dioxide, methane, and nitrous oxide concentrations, has contributed to global warming and thus altered the natural climate system [1,2]. Climate change has already altered the hydrologic cycle components and the response of rainfall-runoff processes [3-5] and the magnitude, frequency, and timing of high flows (floods) and low flows (droughts), including shift in time of occurrence of peak flow hydrographs [2-4,6-9]. These impacts are expected to continue in the future and may have adverse consequences on freshwater resources availability and sustainability [3-5] and related natural habitats [10]. Such effects may have more serious implications on the hydrological regimes and riparian ecosystems of Pacific Islands, where there are limited land and freshwater resources.

Like others in the Pacific, the Hawaiian Islands have limited land and freshwater resources available for drinking water supply, food productions, and ecosystem services. The majority of the drinking water supply for the Hawaiian communities originates from groundwater [11]. However, such resources are generally very sensitive to climate change, particularly to rainfall amounts and patterns [12,13], due to the small-size of the feeding watersheds and the corresponding short water residence time. Over the Hawaiian Islands, the most observed impacts of climate change are related to flooding and droughts as well as streamflow and base flow declines. For example, studies by Oki [14] and Bassiouni and Oki [13] on long-term trends analysis of observed streamflow and baseflow data of the Hawaiian Islands, generally showed an overall significant decline in trends. More importantly, Oahu Island, the most populated Island in the chain, showed the largest downward shift in base flow compared to the other Islands of the Hawaii state $[13,14]$. This is mainly due to an overall decline in rainfall amount over the Islands as evidenced by several studies [15-18] as well as increasing groundwater withdrawal in the most densely populated areas [19]. These previous studies also indicated that Hawaii is expected to face an overall decline in rainfall amount, but the implications of these changes on future streamflows need to be investigated. It is expected that this may cause significant decline in surface and groundwater resources that can lead to restrictions on water use in some areas during droughts. On the other hand, water demand for agricultural productions and other uses is expected to increase. Other factors, such as population growth (http://data.uhero.hawaii.edu/) and increased future water demand [19], can also negatively influence the freshwater availability and sustainability. Furthermore, Diaz et al. [20] and Giambelluca et al. [21] reported that the temperature of the Hawaiian Islands is anticipated to increase in the future, which can increase evapotranspiration rate and further reduce availability of future freshwater resources.

In the long run, climate change, when combined with increased water demand and groundwater withdrawals, can also exacerbate the chance of saltwater intrusion to groundwater aquifers, reduce the amount of groundwater discharge to streams and ocean, cause frequent droughts, and further threaten food security [22]. Thus, the Hawaiian communities are expected to encounter challenges related to freshwater resources availability and sustainability due to hydrological droughts $[3,4,13,23]$. In addition, other consequences include an increase in sea level rise [24-26] and frequent occurrence of extreme events, such as groundwater inundation and flooding especially in low-lying coastal areas leading to groundwater salinization, loss of infrastructures and inhabitants in that zones [27-30]. Such events are anticipated to strongly damage surface and sub-surface drainage and onsite wastewater disposal systems, negatively impact the economy and recreation areas of coastal communities $[29,30]$. For example, Habel et al. [29] reported that future groundwater inundation and flooding due to sea level rise would threaten approximately $\$ 5$ billion of real estate property and municipal infrastructures of Honolulu around Waikiki area. The authors also documented that frequent surficial flooding caused by extreme rainfall events is expected to occur at the coastal communities as a result of groundwater inundation and narrow unsaturated space that limits the amount of water accommodated through infiltration process. Such processes would have significant effect on the economy of Hawaii, as extreme flooding events are projected to cost billions of dollars to repair damaged property and infrastructures of coastal communities [29,31]. 
Despite the development of numerous layers of protection by adopting the Hawaii Legislature for all freshwater bodies (e.g., see the Hawaii State Water Code 2017) and of enforcing policies and approvals of water allocation for all water users of the Islands (e.g., see the State Commission on Water Resources Management (CWRM)), population growth and climate change are still expected to cause further reduction in freshwater and frequent droughts in the state of Hawaii. For example, approximately 0.3 million cubic meters per day of additional water demand is expected by 2030 [32].

The advancements in climate models to predict future climate variables have made increased confidence in their outputs, which are in turn used as inputs to watershed and hydrological models. As a consequence, several studies have shown the impacts of future climate change on freshwater budgets $[5,33-36]$, streamflow $[2,6,7,37,38]$, and hydrological extremes $[6,8-10,39,40]$ at large-scale continental watersheds. In small-scale Pacific island watersheds, such as in Hawaii, a few studies $[3,4,41]$ have also assessed the impact of climate change on water budgets but focused at monthly and yearly mean values. However, there are no watershed-wide assessment of climate change impact on daily streamflow and its extreme values in Hawaii. Estimating the impact of future climate change on water budget elements is of importance for an overall water resources management approach. However, assessing future extreme values is also of critical need due to their significant impact on the economy, environment, and human life [6,29,31]. Additionally, a detailed overview on the possible impacts of future climate change scenarios on streamflow duration curves and hydrological extremes has not been documented yet. Therefore, predicting climate change impacts on hydrological extremes (floods, droughts) and better understanding these impacts are of major importance for Hawaii. Such studies can ultimately help water management and decision makers as an exploratory tool for evaluating the consequences of climate change on hydrological extremes.

This study assesses the impact of climate change on streamflow and hydrological extremes (peak and low flows) by using the statistically downscaled rainfall data over the Hawaiian Islands for the middle century (2041-2070) and the late century (2071-2100) as reported by Timm et al. [18] under the Representative Concentration Pathways (RCP) of 4.5 and 8.5 scenarios [1]. The RCP 4.5 scenario refers to a radiative forcing value of $4.5 \mathrm{~W} \mathrm{~m}^{-2}$, while the RCP 8.5 refers to a radiative forcing value of $8.5 \mathrm{~W} \mathrm{~m}^{-2}$ by the end of 21 st century relative to the pre-industrial values [1,42]. It is projected that greenhouse gas emissions for the RCP 4.5 scenario will reach its peak values around the mid-century and then decline. However, in the case of RCP 8.5 scenario, the emissions are anticipated to continue rising through the 21st century [1]. In this study, we also considered temperature and solar radiation changes based on previous studies $[20,41,43,44]$. The widely used watershed model, Soil and Water Assessment Tool (SWAT) [45] was applied to simulate daily streamflows. SWAT was used for two adjacent watersheds, Kalihi and Nuuanu, which are located on the leeward side of Oahu. The specific objectives of this study were to

a. Simulate daily streamflow and its extreme values of Kalihi and Nuuanu watersheds under current and future climatic conditions;

b. Evaluate and provide a detailed overview of the effects of two extreme climate change scenarios (RCP 4.5 and 8.5) on simulated streamflow (Flow Duration Curve (FDC)) and hydrological extremes (peak and low flows) of the two watersheds.

These objectives were accomplished by calibrating and validating SWAT against daily observed streamflow data measured at three stations by the US Geological Survey (USGS). The climate change impacts were assessed through changes in three critical variables, i.e., rainfall, temperature, and solar radiation for both RCP 4.5 and 8.5 scenarios. Combining the two RCP scenarios with the possible changes of the aforementioned climatic variables helps to better understand and estimate possible range of changes in FDC and extreme peak and low flow values under future climate conditions. 


\section{Materials and Methods}

\subsection{SWAT Model}

SWAT is a physically based, semi-distributed, watershed-scale model that operates at different time scales. The model has been widely used for various projects in Africa, Americas, Asia, Europe, and other continents [46,47], proving the applicability of the model across a broad range of watershed scales and characteristics, and environmental problems. SWAT considers the watershed's spatial heterogeneity and connectivity by discretizing a watershed into a number of sub-basins, which have homogeneous climatic conditions [48]. The model also accounts for sub-basins' land use, soil, and topographic variability by further classifying the delineated sub-basins into a number of hydrological response units (HRUs). HRUs are the smallest spatial-scale of SWAT that refer to a homogenous combination of land use, soil type, and slope value within a sub-basin [49]. The model uses a water balance concept and equation that includes precipitation, surface runoff, actual evapotranspiration, inter flow, percolation, baseflow, and deep groundwater loss components at the HRUs scale [50]. Approaches for estimating these processes are detailed in Neitsch et al. [50]. For this study, we used the modified Curve Number method of the Soil Conservation Service (SCS) [51] for surface runoff simulation whereas the Penman-Monteith method [52] and the variable storage routing method [53] were used for Potential Evapotranspiration (PET) estimation and daily streamflow routing, respectively.

\subsection{Study Area}

The study area consists of the Kalihi and Nuuanu watersheds, which are located in the south-east, leeward side of Oahu (Figure 1). These watersheds were purposely considered in order to cover the spatial extent of the Kalihi and Nuuanu aquifers, which represent extreme hydrological, land use, and topographic gradients and have been modeled by a groundwater modeling system in the later phase of the study. The watersheds approximately cover $51.3 \mathrm{~km}^{2}$. The Nuuanu watershed has four reservoirs, but only the Nuuanu Reservoir \#4 (NR4) (Figure 2a) has significant role on the hydrology of the watershed and is thus considered in the modeling processes. Detailed description about the NR4 can be found in Leta et al. [4].

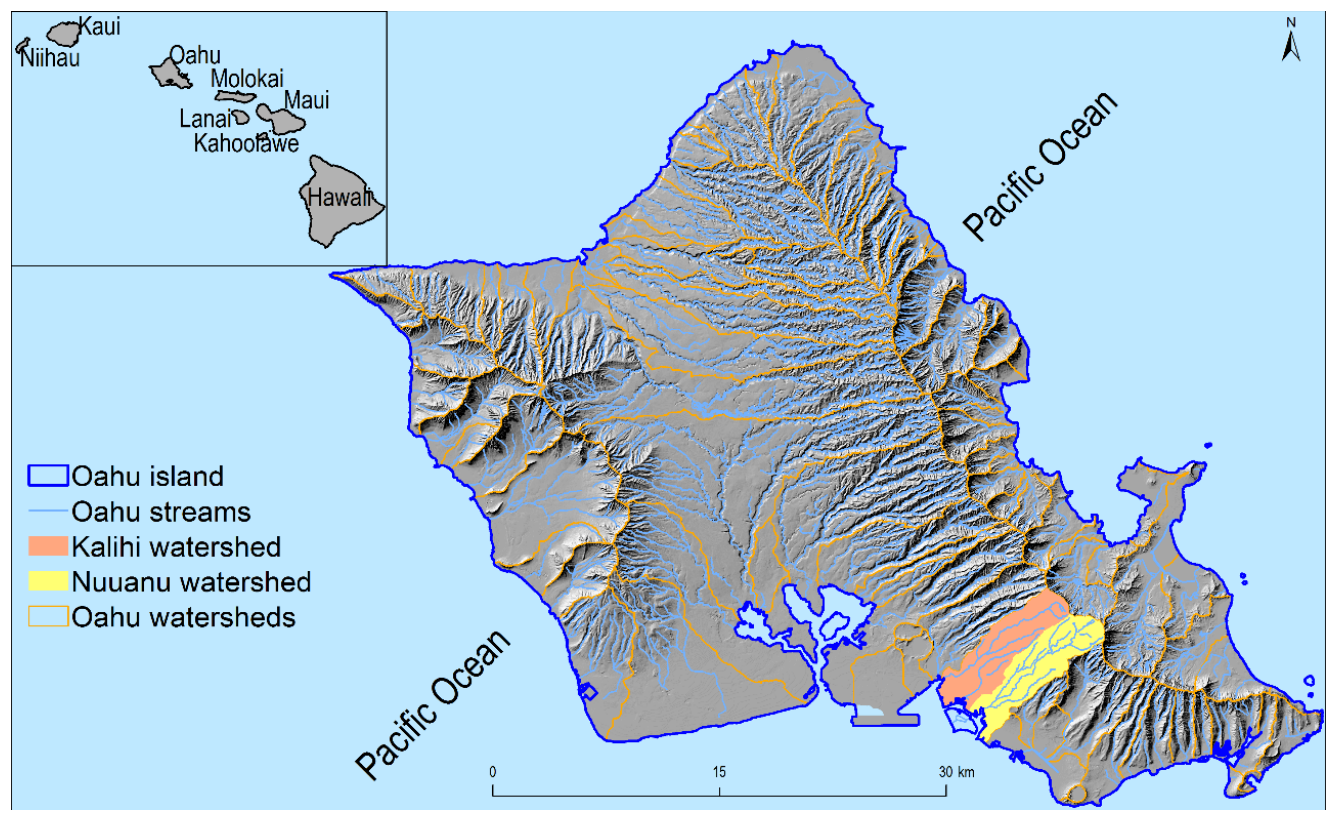

Figure 1. Location of the Oahu Island in Hawaii (top left corner) and the Kalihi and Nuuanu watersheds on Oahu, with their streams. 


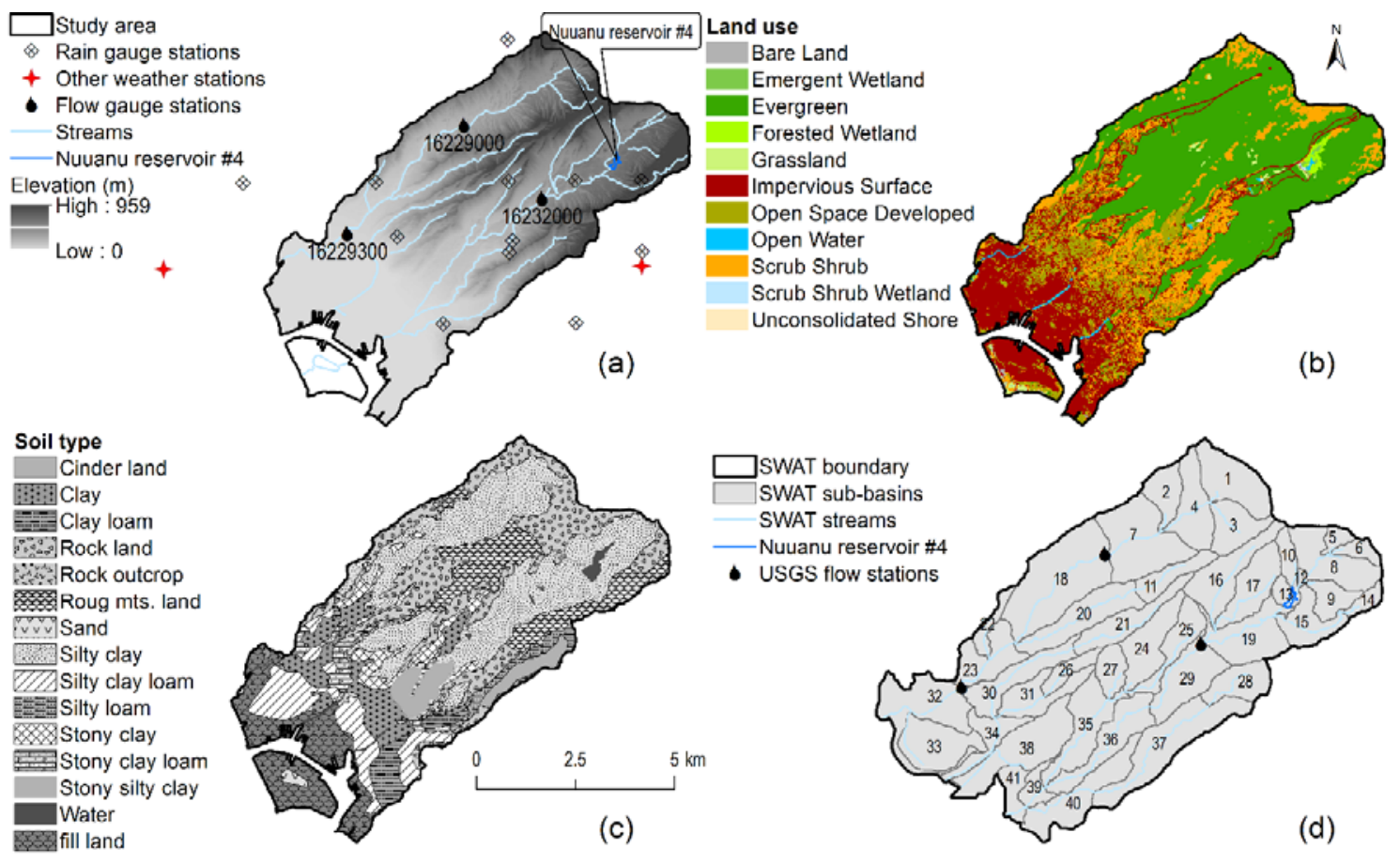

Figure 2. Digital Elevation Model (DEM) with hydro-meteorological stations (a); land use (b); soil type (c); and Soil and Water Assessment Tool (SWAT) delineated sub-basins (d).

While the average slope of the watersheds is $34.5 \%$ with standard deviation of $36 \%$, the elevation ranges from 0 to $959 \mathrm{~m}$ above mean sea level (AMSL). Evergreen forest that covers approximately $52 \%$ of the watersheds mainly exist in the upstream part, while the lowland part of the watersheds is impervious surface that accounts for nearly $36 \%$ of the watershed areas and followed by scrub-shrub land use (6\%) (Figure $2 \mathrm{~b})$. Silty clay $(28 \%)$, rock land $(19 \%)$, and fill land $(11 \%)$ are the dominant soils among others (Figure 2c).

\subsection{Data}

We collected the required geospatial and hydro-climate data from different sources. Geospatial data, such as a $10 \times 10 \mathrm{~m}$ Digital Elevation Model (DEM) obtained from the Department of Commerce (DOC), National Oceanic and Atmospheric Administration (NOAA), Center for Coastal Monitoring and Assessment (CCMA), 1:24,000 scale soil maps from the Soil Survey Geographic (SSURGO) database as provided by the U.S. Department of Agriculture and Natural Resources Conservation Service (USDA-NRCS) (http:/ / www.nrcs.usda.gov/wps/portal/nrcs/surveylist/soils/survey/state/ ?stateId=HI), and a $2.4 \times 2.4 \mathrm{~m}$ land use map of 2011 from the NOAA Coast Change Analysis Program (C-CAP) (https:/ / coast.noaa.gov/ccapatlas/).

The climate data of the watersheds, such as daily rainfall, minimum and maximum temperature, relative humidity, wind speed, and solar radiation, were obtained from various sources. Rain gauge data collected by the NOAA National Climatic Data Center (NCDC) at several rain gauging stations within and around the watersheds were used for the period 1980 to 2014 (Figure 2a). However, the other data (temperature, relative humidity, wind speed, and solar radiation) were only available in the surrounding watersheds from the NCDC and the Western Regional Climate Center (WRCC). Furthermore, all the climatic data were obtained for the period 1980 to 2014, but there were no recorded solar radiation data before 2000. For the period prior to 2000, we used the SWAT's built-in weather generator tool developed for the US. Missing values of the other climatic data were filled based on contour maps and interpolation techniques. Finally, for optimal model parameter estimation, daily streamflow data recorded at the three USGS flow gauging stations were used (Figure 2a). Measured 
streamflow data were available for the period 1980 to present at 16229000, 1980 to 2004 at 16229300, and 1980 to 1995 at 16232000 .

\subsection{SWAT Set-Up, Calibiration, and Validation}

The SWAT model was developed for the Kalihi and Nuuanu watersheds based on the DEM, land use, soil type, and available hydro-meteorological data. The watershed was divided into 41 sub-basins (Figure 2d) that further sub-divided into various HRUs. Zero threshold values for land use, soil type, and slope value were used during HRUs definition. We used the Sequential Uncertainty Fitting (SUFI2) algorithm [54] for model calibration and parameter estimation procedures. The process was carried-out by setting the lower and upper limits of the SWAT parameter values. The SWAT simulation was divided into three periods consisting of two years of warming-up period to initialize the state variables of the system, a calibration period, and a validation period. We set up the model for the period 1980 to 2014, but, depending on the availability of daily observed streamflow data, the calibration and validation periods varied at the three streamflow gauging stations (Figure 2a).

Prior to calibration, a sensitivity analysis (SA) was conducted using the global Latin Hypercube-One-factor-At-a-Time (LH-OAT) technique [55] of SWAT Calibration and Uncertainty Program (SWAT-CUP) [54]. The minimum and maximum values of the SWAT parameters were fixed based on the ranges given in SWAT and SWAT-CUP guidelines [49,54], including our experience and knowledge for the watersheds. The study used the modified version of SWAT for the Hawaiian watersheds that considers high initial rainfall abstraction for volcanic soils [3].

\subsection{SWAT Performance Evaluation}

We assessed SWAT performance using three statistical evaluation criteria as a single statistical indicator only evaluates a specific part of the streamflow hydrographs [56-58]. The criteria are the Nash-Sutcliffe efficiency (NSE) [59], the percent bias (PBIAS) [56], and the coefficient of determination $\left(R^{2}\right)$ [58]. NSE is a normalized statistical indicator that evaluates the relative magnitude of the residual variance compared to the observed streamflow variance. However, this indicator is not sensitive to the systematic model over- or under-estimation, especially for the low flows [60]. PBIAS evaluates the overall tendency of simulated streamflow to be larger or smaller than observed streamflow values, with a negative (positive) value for model underestimation (overestimation) bias [60]. $R^{2}$ evaluates the degree of the linear relationship between observed and simulated flows, but it is insensitive to the difference in magnitude between observed and simulated streamflow data [58]. We also used a graphical comparison between observations and simulations.

We further evaluated SWAT performance by using the percent of observations bracketed (p-factor) and the average width of uncertainty band to observation standard deviation ratio (r-factor) at 95\% confidence interval (95PCI) [54]. The 95PCI generally accounts for the total model prediction uncertainty calculated at 2.5 and 97.5 percentiles [61]. Yang et al. [61] stated that a good calibration and predictive uncertainty is achieved when p-factor is close to 1 and the r-factor is close to 0 . However, due to measurement errors and other input uncertainties, this may not always be achieved and needs compromise [54]. SUFI2 was run for 500 simulations, but the 95PCI uncertainty was assessed only for those simulations that provided a behavioral solution (threshold value) of NSE $\geq 0.5$.

\subsection{Climate Change Scenarios}

Assessing the impact of future climate change on streamflow requires future climate change projections. Several Global Climate Models (GCMs) [1] have been developed to project future climate data and determine the effects of the increase of greenhouse gas emissions on rainfall, temperature, solar radiation, evapotranspiration, and other variables at a global scale. However, such data cannot be directly used as input for small-scale watershed models, such as SWAT, and thus need further downscaling to obtain finer resolutions [62]. The finer resolutions have been achieved by using statistical or dynamical downscaling techniques $[18,63]$. In this study, we used the statistically 
downscaled rainfall data (anomaly report) for the Hawaiian Islands [18], which considered the Hawaiian local climate conditions, interactions, and topographic characteristics. The rainfall change projections were based on the Intergovernmental Panel on Climate Change (IPCC) Fifth Assessment Report (AR5) [1]. Timm et al. [18] projected the seasonal rainfall anomalies of Hawaii over the representative 30 years of the middle (2041-2070) and late (2071-2100) of the 21st century. Hereafter, the two periods are referred to 2050s and 2080s, respectively. Timm et al. [18] also separately reported downscaled rainfall anomalies for the wet (November to April) and dry (May to October) seasons of Hawaii, under both the RCP of 4.5 and 8.5 scenarios [1]. Moreover, they also produced spatially interpolated projected rainfall anomalies for both wet and dry seasons. The data were available as GIS layers, consisting of eight GIS coverages that represent four dry seasons (2050s, 2080s) and four wet seasons (2050s, 2080s). Table 1 summarizes the minimum and maximum spatially interpolated rainfall anomalies of the eight GIS coverages of the study site for both RCP 4.5 and 8.5 scenarios.

Table 1. Range of rainfall spatial anomalies for the Kalihi and Nuuanu watersheds and parameters of the six climate change scenarios for the period 2041-2070 (2050s) and 2071-2100 (2080s).

\begin{tabular}{|c|c|c|c|c|c|c|c|}
\hline \multirow[b]{2}{*}{ Scenario } & \multirow[b]{2}{*}{ Name } & \multirow[b]{2}{*}{ Period } & \multicolumn{2}{|l|}{ Rainfall (\%) ${ }^{a}$} & \multirow{2}{*}{$\begin{array}{l}\text { Temperature } \\
\left({ }^{\circ} \mathrm{C}\right)^{b}\end{array}$} & \multicolumn{2}{|c|}{ Solar Radiation (\%) ${ }^{\mathrm{c}}$} \\
\hline & & & Wet Season & Dry Season & & $\begin{array}{l}\text { Wet } \\
\text { Season }\end{array}$ & $\begin{array}{l}\text { Dry } \\
\text { Season }\end{array}$ \\
\hline \multirow{2}{*}{ RCP 4.5 (rain) } & \multirow{2}{*}{$\mathrm{RF}$} & $2041-2070$ (2050s) & -17.0 to 3.8 & -29.0 to -6.2 & & & \\
\hline & & $2071-2100(2080 \mathrm{~s})$ & -21.4 to 7.3 & -31.2 to5.9 & & & \\
\hline \multirow{2}{*}{$\begin{array}{l}\text { RCP } 4.5 \text { (rain + } \\
\text { temp) }\end{array}$} & \multirow{2}{*}{ RF-T } & $2041-2070$ (2050s) & -17.0 to 3.8 & -29.0 to -6.2 & 1.0 & & \\
\hline & & $2071-2100$ (2080s) & -21.4 to 7.3 & -31.2 to 5.9 & 1.5 & & \\
\hline \multirow{2}{*}{$\begin{array}{l}\text { RCP } 4.5 \text { (rain }+ \\
\text { temp + solar) }\end{array}$} & \multirow{2}{*}{ RF-T-S } & $2041-2070$ (2050s) & -17.0 to 3.8 & -29.0 to -6.2 & & -5.0 & 5.0 \\
\hline & & $2071-2100$ (2080s) & -21.4 to 7.3 & -31.2 to 5.9 & & -10.0 & 10.0 \\
\hline \multirow{2}{*}{ RCP 8.5 (rain) } & \multirow{2}{*}{ RF } & $2041-2070(2050 \mathrm{~s})$ & -18.6 to 9.5 & -39.1 to -7.1 & & & \\
\hline & & $2071-2100$ (2080s) & -26.2 to 13.9 & -47.7 to -10.8 & & & \\
\hline \multirow{2}{*}{$\begin{array}{l}\text { RCP } 8.5 \text { (rain + } \\
\text { temp) }\end{array}$} & \multirow{2}{*}{ RF-T } & $2041-2070$ (2050s) & -18.6 to 9.5 & -39.1 to -7.1 & 1.5 & & \\
\hline & & $2071-2100(2080 \mathrm{~s})$ & -26.2 to 13.9 & -47.7 to -10.8 & 2.0 & & \\
\hline \multirow{2}{*}{$\begin{array}{l}\text { RCP } 4.5 \text { (rain + } \\
\text { temp + solar) }\end{array}$} & \multirow{2}{*}{ RF-T-S } & $2041-2070$ (2050s) & -18.6 to 9.5 & -39.1 to -7.1 & & -10.0 & 10.0 \\
\hline & & $2071-2100(2080 \mathrm{~s})$ & -26.2 to 13.9 & -47.7 to -10.8 & & -15.0 & 15.0 \\
\hline
\end{tabular}

RCP: Representative Concentration Pathways; ${ }^{\text {a }}$ Timm et al. [18]; ${ }^{b}$ Diaz et al. [20], Safeeq \& Fares [41]; ${ }^{\mathrm{c}}$ Meteorology \& CSIRO [43]; Longman et al. [44].

SWAT utilizes climatic data, including precipitation, temperature, relative humidity, wind speed, and solar radiation, from different gauging stations. However, the model selects only one station per sub-basin, based on proximity to the centroid of the sub-basin. Considering this, the spatially interpolated rainfall anomalies of Timm et al. [18], for example, as shown in Figure 3 (top) cannot be directly used by SWAT. To resolve this issue, including accounting for the uncertainty of projected rainfall anomalies, we first estimated the lower and upper rainfall anomaly values of Timm et al. [18] for each sub-basin. This was done by overlaying the rainfall anomaly and the SWAT delineated sub-basin maps (see Figure 3, as an example). Then, in order to capture the lower and upper anomalies per a sub-basin, the sub-basin's daily rainfall values of 1980 to 2014 were perturbed based on the estimated lower and upper rainfall anomalies of each sub-basin (Figure 3, bottom). Such an approach resulted in four scenarios: one for the lower bound and the other for the upper bound for each of the RCP 4.5 and 8.5 scenarios. Hereafter, the lower and upper bound rainfall changes are called rainfall min (RFmin) and rainfall max (RFmax), respectively. This approach assured that the possible range of rainfall changes was bracketed and allowed full assessment of their impacts on future streamflow availability and hydrological extremes. 

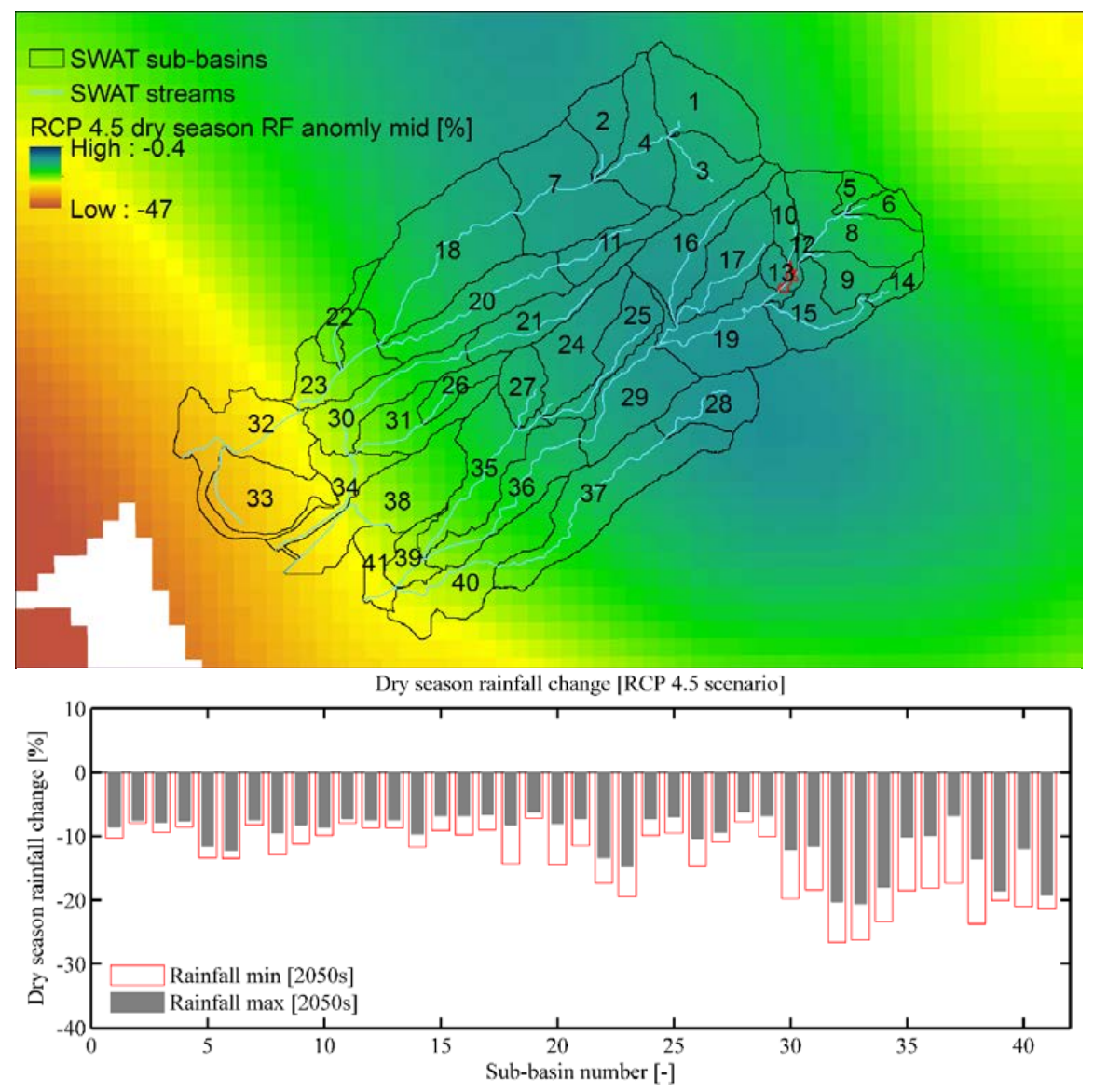

Figure 3. Projected rainfall anomaly for the dry season (2050s) overlaid with delineated sub-basins (Top) and lower and upper rainfall anomaly within sub-basins (Bottom).

The climate change impact analysis also included the expected change in future temperature and solar radiation for the Hawaiian Islands [20,41]. Based on previous studies, we assumed the maximum and minimum temperatures to increase by $1{ }^{\circ} \mathrm{C}$ for the 2050s and $1.5^{\circ} \mathrm{C}$ for the $2080 \mathrm{~s}$ under the RCP 4.5 scenario and by $1.5^{\circ} \mathrm{C}(2050 \mathrm{~s})$ and $2{ }^{\circ} \mathrm{C}$ (2080s) for the RCP 8.5 scenario. In the absence of available projection data, expected change in solar radiation was also assessed based on previous studies. Recent study on the Maui Island of Hawaii indicated that historical solar radiation showed increasing trends during dry season (due to decreasing cloud cover), but decreasing trends during the wet season over the period 1988 to 2012 [44]. Further, the Australian Bureau of Meteorology and Commonwealth Scientific and Industrial Research Organization (CSIRO) [43] projected similar future decrease in solar radiation during the wet season, but increase during dry season over the Pacific Islands. Based on these studies $[43,44]$, we increased the baseline solar radiation values of the dry season by $5 \%(2050 \mathrm{~s})$ to $10 \%$ (2080s) for the RCP 4.5 scenario and 10\% (2050s) to $15 \%$ (2080s) for the RCP 8.5 scenario. The same magnitudes were applied to decrease the solar radiation values of the wet season.

Three climate change scenarios were formulated, perturbing rainfall alone, perturbing rainfall and temperature, and finally a scenario when a combination of rainfall, temperature, and solar radiation changes was assumed (Table 1). Such formulations allow us to better understand the sensitivity of streamflow and hydrological extreme values to changes of those climate variables. For rainfall and solar radiation changes, the baseline values were increased or decreased by multiplying by factors with a value of one meanings no change. For example, for the solar radiation, during dry season, a value of 1.05 (2050s) was used, indicating a $5 \%$ increase in solar radiation compared to the historical data. Similarly, a change value of 0.95 was used during the wet season to reflect a $5 \%$ decrease in solar radiation value compared with the baseline values by the mid of the 21st century. Absolute 
values were used for the temperature change. The perturbation values of rainfall, temperature, and solar radiation changes provided in Table 1 were implemented in SWAT's sub-basin input files [49]. The table also summarizes the six scenarios that were formulated for RCP 4.5 and 8.5.

\subsection{Streamflow and Extreme Value Analysis}

In order to assess the impact of future climate change on daily streamflow values, we used the relative changes of future FDC to baseline values. Based on the six climate change scenarios mentioned in Table 1, we computed the ensemble ranges and the corresponding average values of the ensemble range of relative changes. The ensemble range and average values were calculated for the 2050s and 2080s periods. Such an approach facilitates the assessment of the effect of minimum and maximum of rainfall, temperature, and solar radiation changes on daily streamflow.

For daily streamflow extremes (extreme peak and low flows) analysis, we used the Water Engineering Time Series PROcessing (WETSPRO) tool developed by Willems [64]. By using this tool, we estimated the extreme peak flow values, which were selected based on the peak over threshold (POT) method as described in Willems [64]. The SWAT simulated daily streamflows under the baseline and future climate change scenarios were used in such an analysis. Similarly, the WETSPRO tool was used to estimate the low flow values, which were selected on the basis of the lowest annual flow value [64]. Both the selected extreme peak and low flow values were then ranked from high to low and low to high, respectively, and the corresponding return periods were estimated as

$$
T=\frac{N+1}{r}
$$

where $T$ is the return period [year] corresponding to the peak or low flow of rank $r$ and $N$ is the total number of years of simulation period. Relative changes in extreme peak and low flows were plotted against the calculated return periods. Detailed approaches on extreme peak and low flows selection are described by Willems [64].

\section{Results and Discussion}

\subsection{Streamflow Simulation}

On the basis of sensitive and important parameters, which were identified by Leta et al. [4] for the watersheds, the SWAT model was calibrated and validated for a number of years of streamflow data at the three USGS flow gauging stations (Table 2). The parameter values as reported by Leta et al. [4] were also used. The goodness-of-fit statistics evaluating the performance of SWAT at the three stations are given in Table 2. While the study calibrated and validated the model for several years, as an example, the results for one year of streamflow hydrographs with the respective $95 \%$ prediction uncertainty are shown in Figure 4. However, Figure 5 presents the scatter plots that cover all the calibration and validation periods.

Table 2. Goodness-of-fit statistics for the daily streamflow at the three US Geological Survey (USGS) flow gauging stations.

\begin{tabular}{ccllccccc}
\hline Watershed & Station No. & Period & Time Span & $p$-Factor & $\boldsymbol{r}$-Factor & NSE & PBIAS (\%) & $\boldsymbol{R}^{\mathbf{2}}$ \\
\hline \multirow{3}{*}{ Kalihi } & \multirow{2}{*}{16229000} & Calibration & $2006-2010$ & 0.83 & 0.84 & 0.86 & 14.7 & 0.86 \\
\cline { 3 - 9 } & \multirow{2}{*}{16229300} & Validation & $2011-2014$ & 0.93 & 0.72 & 0.88 & 1.1 & 0.88 \\
\cline { 3 - 9 } & \multirow{2}{*}{16232000} & Calibration & $2000-2004$ & 0.86 & 0.45 & 0.80 & 8.6 & 0.80 \\
\cline { 3 - 9 } & & Validation & $1995-1999$ & 0.91 & 0.98 & 0.58 & 24.2 & 0.62 \\
\cline { 3 - 9 } & & Calibration & $1990-1995$ & 0.93 & 0.78 & 0.72 & 8.8 & 0.75 \\
\hline \multirow{2}{*}{ Nuuanu } & Validation & $1985-1989$ & 0.90 & 0.46 & 0.58 & 11.3 & 0.60 \\
\hline
\end{tabular}

$p$-factor $=$ percent of observations bracketed at 95\% confidence interval $(95 \mathrm{PCI}) ; r$-factor $=$ width of 95PCI; NSE = Nash-Sutcliffe Efficiency; PBIAS = Percent bias; $R^{2}=$ coefficient of determination. 


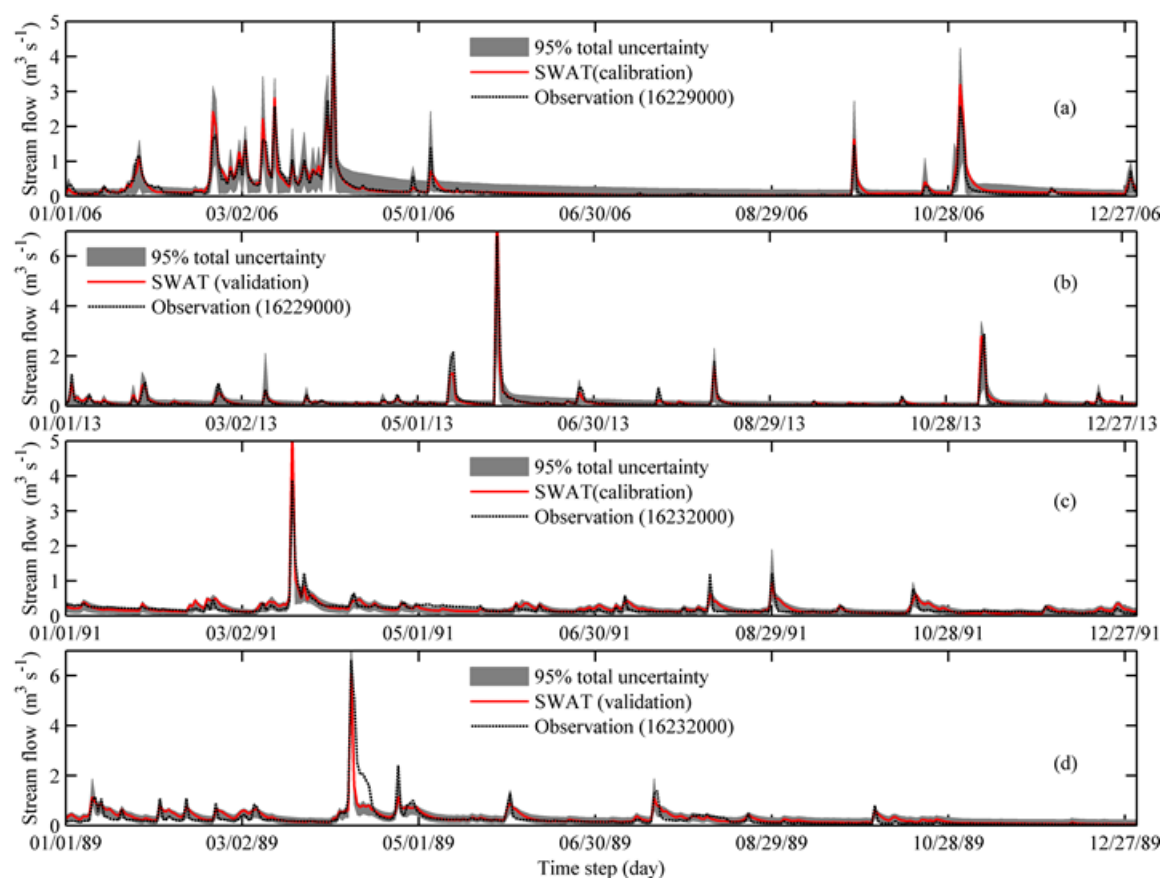

Figure 4. Simulated and observed daily streamflow hydrographs of Kalihi watershed at 16229000 (a,c) and Nuuanu watershed at $16232000(\mathbf{b}, \mathbf{d})$ for calibration and validation periods.
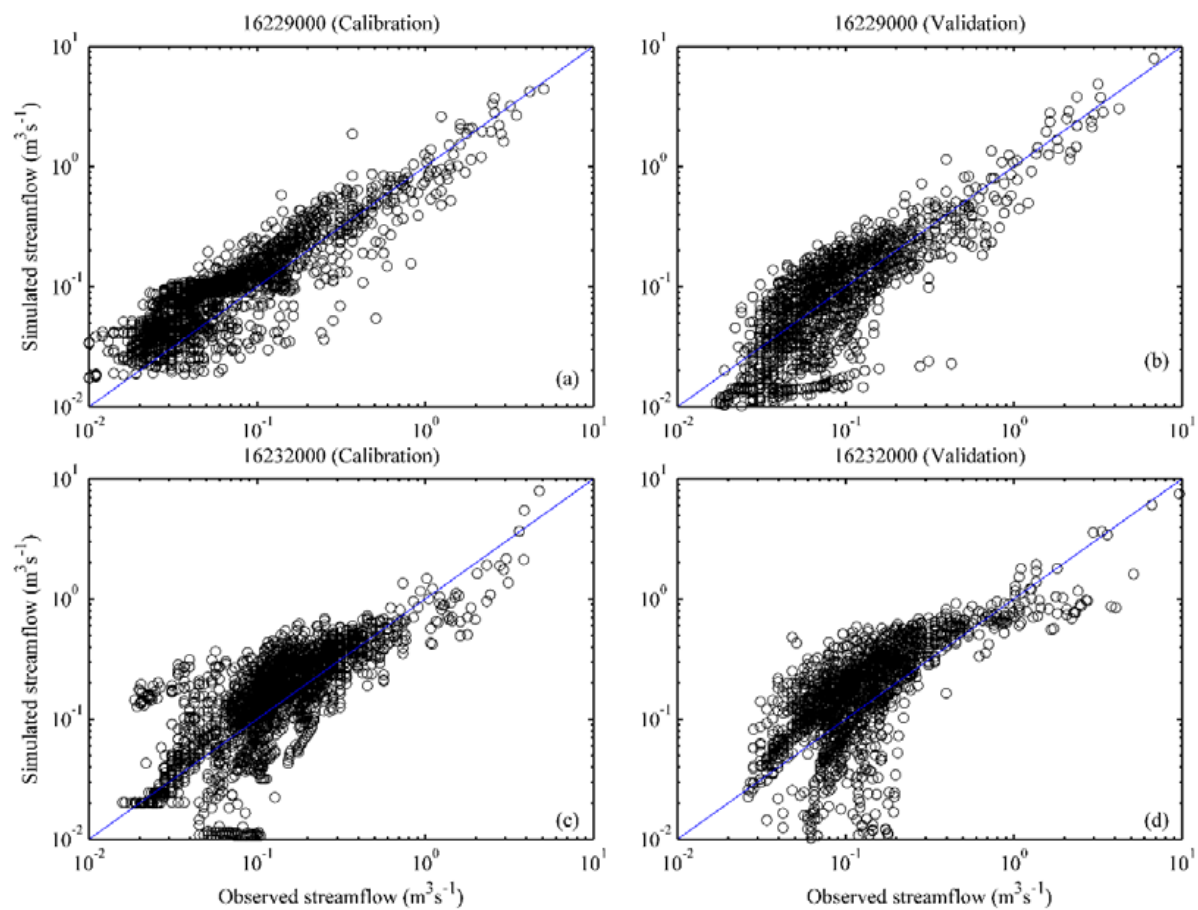

Figure 5. Daily observed and simulated streamflow for the Kalihi $(\mathbf{a}, \mathbf{b})$ and the Nuuanu (c,d) watersheds during the calibration and validation periods.

Figure 4 generally indicates the suitability of SWAT to predict daily streamflows as the simulated values and their temporal variability acceptably match the observations. This is also further evidenced with NSE values of 0.58 to 0.88 for both the calibration and validation periods (Table 2). The performance of the model at 16229300 (validation only) and 16232000 stations is somewhat reduced when compared to the 16229000 station. This could be related to lack of solar radiation 
data for before 2000, since we used SWAT's weather generator tool to fill radiation data of before 2000. As solar radiation is found to be essential for Hawaii's evapotranspiration estimation $[65,66]$ and thus streamflow, the use of weather generator data probably caused lower model performance during the validation periods at 16229300 as well as at 16232000 , in comparison with the periods that used observed solar radiation values. Further evaluation using the $95 \%$ model prediction uncertainty shows that more than $80 \%$ of the observations at all stations are bracketed within the 95PCI with an average uncertainty band width of close to 1 (Table 2). Furthermore, the calculated p-factor and $\mathrm{r}$-factor values at all stations (Table 2 ) are above or below the acceptable values, which are $\geq 70 \%$ and $\leq 1.5$, respectively, as recommended by Abbaspour et al. [67].

The results in Figures 4 and 5 generally reveal an overall good accuracy of SWAT, indicating the applicability of the model for streamflow simulations under different watershed conditions. Further, all the statistical evaluation criteria at the three stations showed an overall good model performance (Table 2). Based on such results, confidence was gained to use the model for future prediction of streamflows. Thus, the calibrated and validated SWAT was used for simulating daily streamflow and hydrological extremes under various future climate conditions.

\subsection{Impact of Climate Change on Daily Streamflow}

The calibrated and validated SWAT was run with long-term baseline (1980-2014) and perturbed future climate time series data. The simulated streamflow values under both baseline and future scenarios were post-processed to derive the FDC for the six climate change scenarios of the middle and late of the 21st century for each of the RCP 4.5 and 8.5 scenarios listed in Table 1. Then, the corresponding relative changes ensemble and average values were estimated.

The relative sensitivity of FDC to various climate change scenarios is summarized in Table 3 for both RCP 4.5 and 8.5 scenarios. The results in the table show the wide range of the impact on FDC for the 2050s and 2080s. For example, the FDC change is in the range of -43.4 to $7.3 \%$ for Kalihi and -54.1 to $21.6 \%$ for Nuuanu. The table also shows an overall decrease in the predicted FDC values when compared to the baseline values under both scenarios. However, a relatively small increase in FDC values would happen, which is likely due to an increase in rainfall amount during the wet season as summarized in Table 1. Studies by Leta et al. [4] also reported similar findings on the impact of climate change on reservoir outflow duration curves of the NR4. In contrast, a more pronounced downward trend in FDC is noted during the dry season (high probability of exceedance), irrespective of the applied scenarios (Figures 6 and 7), which is also consistent with the projected rainfall anomalies listed in Table 1. As a consequence, the flow curves are expected to shift downwards to lower values (Figures 6 and 7). The figures also indicate that more deviation from the baseline values is expected for medium to low flows (probability exceedance of $\geq 0.6$ ). Such characterization implies the earlier occurrence of lower values compared to the current hydrological regime. This could be because of a consistent decrease in rainfall and increase in temperature and solar radiation during the dry season as shown in Table 1 and Figure 3.

Table 3. Minimum (min), average (avg.), and maximum (max) changes in flow duration curves relative to the baseline for Representative Concentration Pathways (RCP) 4.5 and 8.5 scenarios.

\begin{tabular}{|c|c|c|c|c|c|c|c|c|c|c|c|}
\hline \multirow{3}{*}{ Scenario } & \multirow{3}{*}{ Period } & \multirow{3}{*}{ Changed Variable } & \multicolumn{9}{|c|}{ Relative Change (\%) } \\
\hline & & & \multicolumn{3}{|c|}{ Kalihi (16229000) } & \multicolumn{3}{|c|}{ Kalihi (16229300) } & \multicolumn{3}{|c|}{ Nuuanu (16232000) } \\
\hline & & & Min & Avg. & Max & Min & Avg. & Max & Min & Avg. & Max \\
\hline \multirow{6}{*}{ RCP 4.5} & \multirow{3}{*}{$2050 \mathrm{~s}$} & $\mathrm{RF}$ & -25.4 & -9.8 & 3.0 & -20.7 & -9.6 & 0.5 & -28.7 & -8.7 & 5.4 \\
\hline & & RF-T & -29.3 & -12.6 & 1.2 & -22.0 & -12.0 & 0.3 & -32.3 & -10.7 & 4.4 \\
\hline & & RF-T-S & -30.8 & -13.0 & 0.0 & -22.7 & -12.3 & 0.1 & -32.9 & -11.0 & 4.4 \\
\hline & \multirow{3}{*}{$2080 \mathrm{~s}$} & $\mathrm{RF}$ & -27.1 & -9.9 & 2.4 & -21.7 & -9.6 & 2.5 & -30.2 & -8.3 & 11.0 \\
\hline & & RF-T & -32.6 & -13.9 & 1.2 & -24.0 & -12.9 & 1.5 & -36.0 & -11.2 & 8.5 \\
\hline & & RF-T-S & -34.8 & -14.8 & 1.8 & -25.5 & -13.5 & 1.8 & -37.8 & -11.7 & 8.7 \\
\hline
\end{tabular}


Table 3. Cont

\begin{tabular}{|c|c|c|c|c|c|c|c|c|c|c|c|}
\hline \multirow{3}{*}{ Scenario } & \multirow{3}{*}{ Period } & \multirow{3}{*}{ Changed Variable } & \multicolumn{9}{|c|}{ Relative Change (\%) } \\
\hline & & & \multicolumn{3}{|c|}{ Kalihi (16229000) } & \multicolumn{3}{|c|}{ Kalihi (16229300) } & \multicolumn{3}{|c|}{ Nuuanu (16232000) } \\
\hline & & & Min & Avg. & Max & Min & Avg. & Max & Min & Avg. & Max \\
\hline \multirow{6}{*}{$\mathrm{RCP} 8.5$} & \multirow{3}{*}{ 2050s } & RF & -29.4 & -10.4 & 3.5 & -24.7 & -9.8 & 4.5 & -32.4 & -8.2 & 13.8 \\
\hline & & RF-T & -34.8 & -14.4 & 3.5 & -27.2 & -13.3 & 3.4 & -39.0 & -11.2 & 13.7 \\
\hline & & RF-T-S & -36.6 & -15.1 & 3.6 & -28.3 & -13.8 & 4.1 & -40.5 & -11.6 & 14.0 \\
\hline & \multirow{3}{*}{$2080 \mathrm{~s}$} & $\mathrm{RF}$ & -36.6 & -14.4 & 5.6 & -32.2 & -13.2 & 7.3 & -46.4 & -12.0 & 21.6 \\
\hline & & RF-T & -41.6 & -19.3 & 5.0 & -34.0 & -17.5 & 5.9 & -51.8 & -15.9 & 19.8 \\
\hline & & RF-T-S & -43.4 & -20.2 & 5.9 & -35.4 & -18.1 & 6.5 & -54.1 & -16.9 & 19.7 \\
\hline
\end{tabular}

$\mathrm{RF}=$ rainfall $; \mathrm{T}=$ temperature; $\mathrm{S}=$ solar radiation.
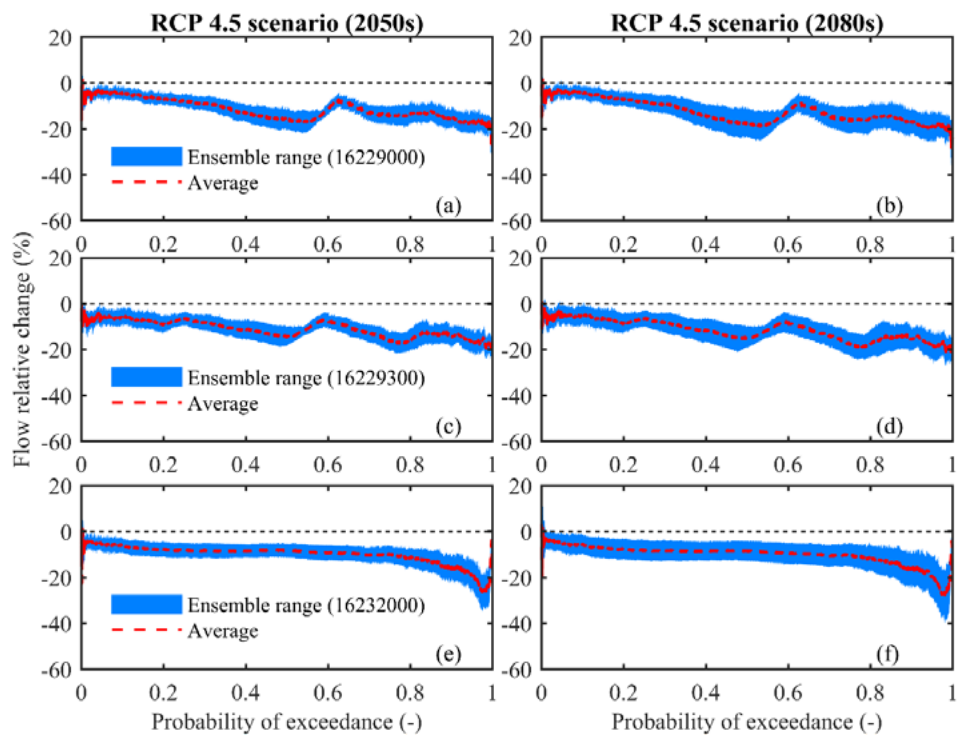

Figure 6. Relative changes in flow duration curves compared to baseline for Kalihi (a-d) and Nuuanu (e,f) watersheds by 2050s (Left) and 2080s (Right) of the Representative Concentration Pathways (RCP) 4.5 scenario.

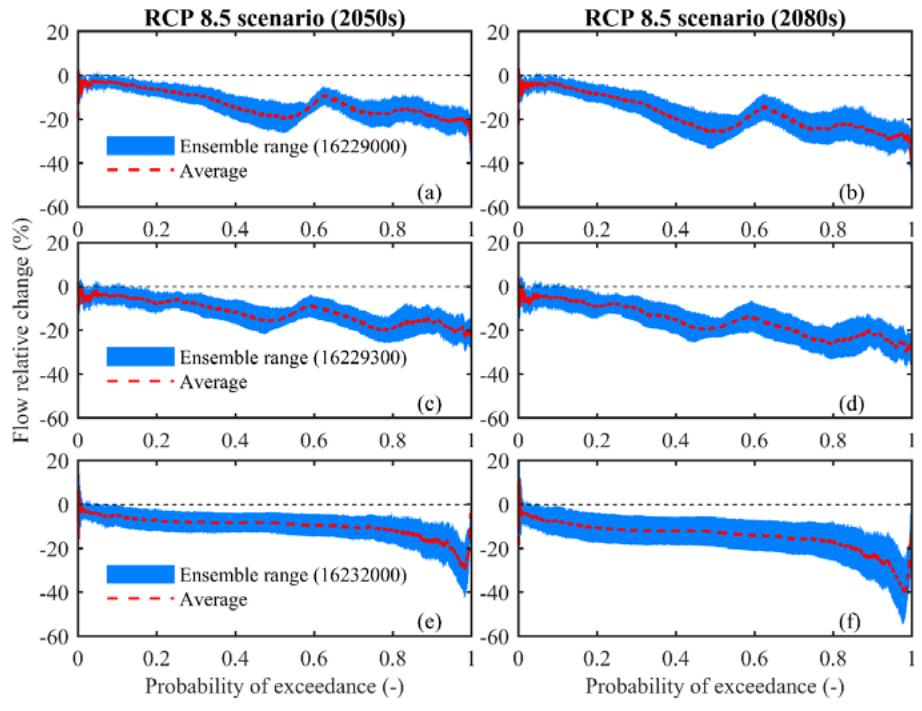

Figure 7. Relative changes in flow duration curves compared to baseline for Kalihi (a-d) and Nuuanu (e,f) watersheds for 2050s (Left) and 2080s (Right) of the Representative Concentration Pathways (RCP) 8.5 scenario. 
More importantly, Table 3 highlights that rainfall is the main influential for the downward shift of FDC as compared to temperature and solar radiation changes. For example, a rainfall change alone is expected to decrease streamflow values by as much as $25 \%$ for the Kalihi watershed and $29 \%$ for the Nuuanu watershed whereas superimposing temperature change just increases to $29 \%$ and $32 \%$, respectively. An increase in temperature is expected to cause a more downward shift in FDC, in comparison to rainfall change alone, but if change in solar radiation effect is considered during the wet season, the result is a reduced effect of temperature on FDC, especially for flows with low chance of exceedance (Figures 6 and 7).

Similar trends in changes of FDC are observed for both RCP 4.5 and 8.5 scenarios (Figures 6 and 7). However, the RCP 8.5 scenario is expected to lead to larger negative and positive changes in FDC (Table 3) with a wider ensemble range of relative changes. For example, by the end of 2080s, the maximum decrease in streamflow of Nuuanu watershed is approximately $38 \%$ and $54 \%$ for RCP 4.5 and 8.5 scenarios, respectively. In general, compared to RCP 4.5, relatively drier (dry season) and wetter (wet season) season is projected for RCP 8.5 scenario. Therefore, an overall decline in streamflow is expected by the later period of this century. Finally, relative changes on medium to low flows are high as wider relative changes are predicted for flows that have high chance of exceedance (Figures 6 and 7). Such results imply severe problems with freshwater availability and sustainability during the dry period that in turn affects the groundwater reservoir of the study area, the main drinking water source in Hawaii.

In general, the overall impact of climate change on daily streamflow shows downward flow trends. These results are consistent with previous studies on historical baseflow and streamflow trends by Oki [14] and Bassiouni and Oki [13]. In addition, although there are a few studies on future climate change impacts assessment in Oahu, the studies by Leta et al. [3,4] and Safeeq and Fares [41] showed an overall decline in both monthly and annual streamflow values. Thus, climate change is likely to negatively affect the amount of water discharge to the streams and ocean. Such effects will have serious consequences on human water use, coral reef, and riparian ecosystem functions of Oahu.

\subsection{Impact of Climate Change on Extreme Peak Flows}

Different climate change scenarios listed in Table 1 were considered to assess the relative sensitivity of extreme peak flows to rainfall, temperature, and solar radiation changes. Table 4 summarizes the impact of these changes whereas Figures 8 and 9 show the combined effect of the three main climatic factors on extreme peak flows by the middle and end of this century. The minimum, average, and maximum relative changes to the baseline values were estimated based on the ensemble of the different scenarios.

Table 4. Minimum (min), average (avg.), and maximum ( $\max$ ) changes in extreme peak flow values relative to the baseline for Representative Concentration Pathways (RCP) 4.5 and 8.5 scenarios.

\begin{tabular}{|c|c|c|c|c|c|c|c|c|c|c|c|}
\hline \multirow{3}{*}{ Scenario } & \multirow{3}{*}{ Period } & \multirow{3}{*}{ Name } & \multicolumn{9}{|c|}{ Relative Change (\%) } \\
\hline & & & \multicolumn{3}{|c|}{ Kalihi (16229000) } & \multicolumn{3}{|c|}{ Kalihi (16229300) } & \multicolumn{3}{|c|}{ Nuuanu (16232000) } \\
\hline & & & Min & Avg. & Max & Min & Avg. & Max & Min & Avg. & Max \\
\hline \multirow{6}{*}{$\mathrm{RCP} 4.5$} & \multirow{3}{*}{$2050 \mathrm{~s}$} & $\mathrm{RF}$ & -36.2 & -10.2 & 3.1 & -46.3 & -11.1 & 0.5 & -26.6 & -7.4 & 5.4 \\
\hline & & RF-T & -39.5 & -11.9 & 2.4 & -56.0 & -12.6 & 0.3 & -29.4 & -8.9 & 4.7 \\
\hline & & RF-T-S & -41.2 & -12.2 & 1.2 & -59.5 & -12.8 & 0.1 & -29.1 & -9.1 & 4.4 \\
\hline & \multirow{3}{*}{$2080 \mathrm{~s}$} & RF & -38.6 & -10.1 & 3.7 & -50.8 & -10.4 & 2.5 & -27.7 & -6.1 & 11.0 \\
\hline & & RF-T & -42.4 & -12.8 & 1.5 & -63.0 & -12.8 & 1.5 & -32.3 & -8.6 & 8.5 \\
\hline & & RF-T-S & -45.2 & -13.2 & 1.8 & -68.4 & -13.0 & 1.8 & -34.7 & -8.9 & 8.7 \\
\hline
\end{tabular}


Table 4. Cont.

\begin{tabular}{|c|c|c|c|c|c|c|c|c|c|c|c|}
\hline \multirow{3}{*}{ Scenario } & \multirow{3}{*}{ Period } & \multirow{3}{*}{ Name } & \multicolumn{9}{|c|}{ Relative Change (\%) } \\
\hline & & & \multicolumn{3}{|c|}{ Kalihi (16229000) } & \multicolumn{3}{|c|}{ Kalihi (16229300) } & \multicolumn{3}{|c|}{ Nuuanu (16232000) } \\
\hline & & & Min & Avg. & Max & Min & Avg. & Max & Min & Avg. & Max \\
\hline \multirow{6}{*}{ RCP 8.5} & \multirow{3}{*}{ 2050s } & RF & -41.1 & -10.4 & 3.5 & -60.2 & -10.4 & 4.5 & -28.4 & -5.0 & 13.2 \\
\hline & & RF-T & -46.0 & -12.9 & 3.5 & -71.1 & -12.8 & 3.4 & -34.3 & -7.5 & 13.7 \\
\hline & & RF-T-S & -48.3 & -13.4 & 3.6 & -76.4 & -13.1 & 4.1 & -38.4 & -7.3 & 14.0 \\
\hline & \multirow{3}{*}{$2080 \mathrm{~s}$} & RF & -53.2 & -14.4 & 5.6 & -79.3 & -14.0 & 7.3 & -38.9 & -7.9 & 21.6 \\
\hline & & RF-T & -57.6 & -17.4 & 5.0 & -91.0 & -17.0 & 5.9 & -44.8 & -10.8 & 19.8 \\
\hline & & RF-T-S & -61.2 & -17.9 & 5.9 & -91.7 & -17.2 & 6.5 & -44.5 & -11.2 & 19.7 \\
\hline
\end{tabular}

$\mathrm{RF}=$ rainfall $; \mathrm{T}=$ temperature $\mathrm{S}=$ solar radiation.
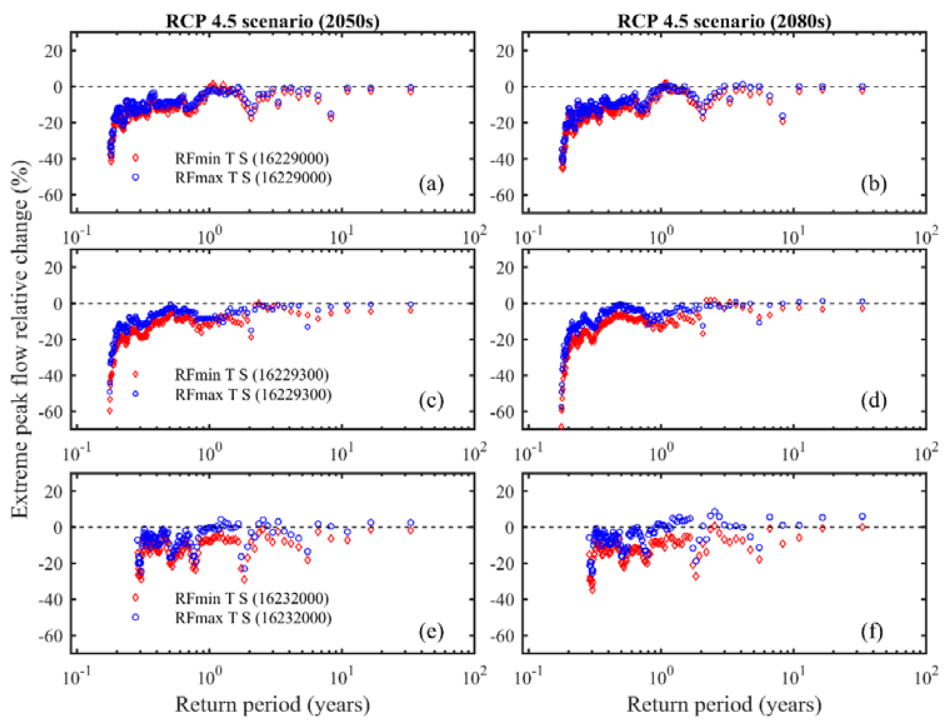

Figure 8. Relative changes in extreme peak flows of Kalihi watershed (a-d) and of Nuuanu watershed (e,f) by 2050s (Left) and 2080s (Right) for the Representative Concentration Pathways (RCP) 4.5 scenario.

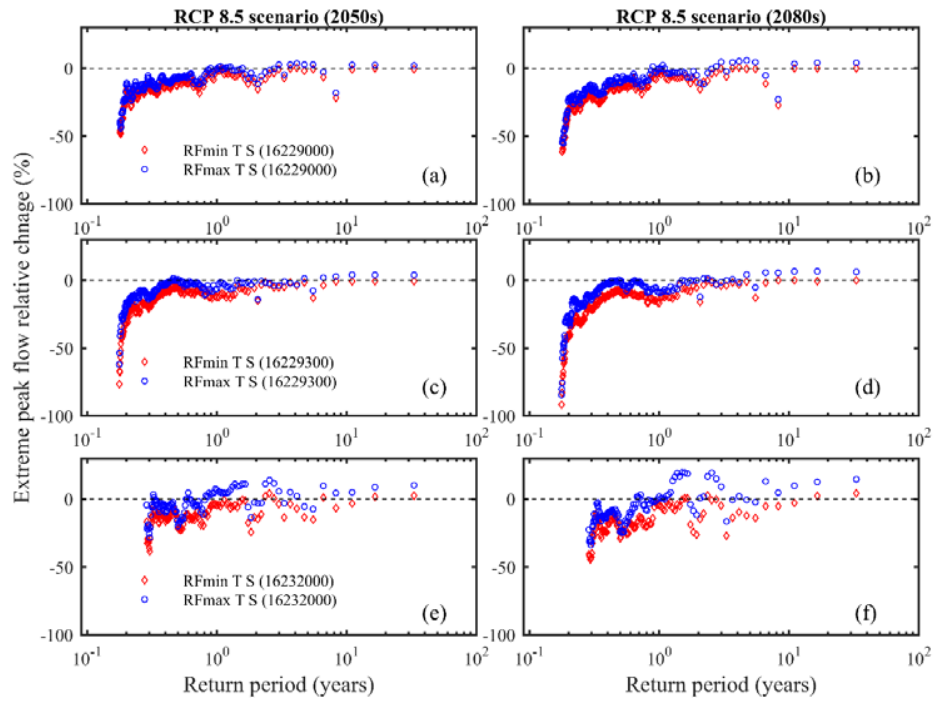

Figure 9. Relative changes in extreme peak flows of Kalihi watershed (a-d) and of Nuuanu watershed (e,f) by 2050s (Left) and 2080s (Right) for the Representative Concentration Pathways (RCP) 8.5 scenario. 
Under RCP 4.5 scenario, extreme peak flows are likely to increase or remain stable for higher return periods, especially for maximum rainfall amount (Table 4 and Figure 8). However, a larger positive change is predicted for RCP 8.5 scenario (Table 4 and Figure 9). Such change is expected for return periods of higher than 4 years (Figure 9), which implies that the baseline distributions are shifted upwards and thus higher peak flows are obtained for the same return periods of the baseline case. This could be due to increase in rainfall, especially during the wet season (see Table 1). Such events of RCP 8.5 scenarios can potentially have adverse consequences, such as damages to infrastructures in the downstream, drainage systems, and loss of aquatic biota [29,31]. It may also cause an increase in the frequency of overflows from the river, which likely results in potential flooding and more sediment transport in the downstream part of the watersheds. Increase in stream sediment loads would have severe consequences for coastal fishponds and coral reefs [68].

Larger negative changes in extreme peak flows are also observed under RCP 8.5 scenario when compared with RCP 4.5 scenario (Table 4). This is particularly noted for return periods of smaller than about 1 year (Figures 8 and 9), which is most likely due to higher negative changes in rainfall during the dry season for the RCP 8.5 scenario (Table 1). In such circumstances, the soil surface may be less saturated (limited moisture availability) and thus may cause a larger initial rainfall abstraction (high infiltration values) that may result in smaller extreme peak flow values compared to the baseline values.

It is clearly seen in Figures 8 and 9 that the response (degree of sensitivity) of the two watersheds to climate change impact on extreme peak flows is different, indicating that climate change impacts are watershed specific. For example, while the Nuuanu watershed showed positive changes or remained stable regarding peak flows, larger negative changes in such flows are noted for the Kalihi watershed. Additionally, stations which are close to the mountainous regions showed relatively smaller change in extreme peak flow values when compared to downstream areas (Table 4, Figures 8 and 9). The latter is likely due to the decrease in solar radiation and therefore evapotranspiration during the wet season and a relatively smaller decrease or stable rainfall close to the mountainous ridge (Figure 3), which has also been reported by Timm et al. [18]. Furthermore, as areas close to the mountain regions receive higher average rainfall amount with expected relatively smaller decrease in rainfall values under climate change (e.g., see Figure 3), a smaller decrease in extreme peak flow values should thus be expected. As a consequence, a larger decrease in extreme peak flows should be expected at the downstream part of the watershed (e.g., at 16229300) in comparison to the upstream part (e.g., at 16229000 and 16232000 stations).

Overall, while the chance of frequent occurrence of flood events is less likely, extreme peak flow events with higher return periods may cause serious damage to the downstream part of the watersheds. An overall wider range in peak flow relative changes of -92 to $22 \%$ is expected under RCP 8.5 (Table 4 ). This indicates the high uncertainty in predicting the impact of future climate change and suggests that serious mitigation measures to climate change should be adapted, particularly if RCP 8.5 scenario should happen.

\subsection{Impact of Climate Change on Extreme Low Flows}

Similar to extreme peak flow values, the impacts of different climate change scenarios on extreme low flows were assessed under RCP 4.5 and 8.5. The minimum, average, and maximum relative changes in low flow values when compared to baseline values are reported in Table 5. 
Table 5. Minimum ( $\mathrm{min}$ ), average (avg.), and maximum (max) changes in extreme low flow values relative to the baseline for RCP 4.5 and 8.5 scenarios.

\begin{tabular}{|c|c|c|c|c|c|c|c|c|c|c|c|}
\hline \multirow{3}{*}{ Scenario } & \multirow{3}{*}{ Period } & \multirow{3}{*}{ Changed Variable } & \multicolumn{9}{|c|}{ Relative Change (\%) } \\
\hline & & & \multicolumn{3}{|c|}{ Kalihi (16229000) } & \multicolumn{3}{|c|}{ Kalihi (16229300) } & \multicolumn{3}{|c|}{ Nuuanu (16232000) } \\
\hline & & & Min & Avg. & Max & Min & Avg. & Max & Min & Avg. & Max \\
\hline \multirow{6}{*}{ RCP 4.5} & \multirow{3}{*}{$2050 \mathrm{~s}$} & $\mathrm{RF}$ & -51.7 & -11.9 & 2.0 & -24.1 & -14.1 & -0.9 & -32.3 & -9.8 & -2.2 \\
\hline & & RF-T & -53.8 & -14.9 & 0.0 & -26.9 & -16.2 & -1.7 & -37.1 & -12.1 & -3.0 \\
\hline & & RF-T-S & -54.3 & -15.6 & 1.7 & -28.1 & -16.9 & -1.2 & -36.9 & -12.3 & -3.0 \\
\hline & \multirow{3}{*}{$2080 \mathrm{~s}$} & $\mathrm{RF}$ & -52.2 & -12.3 & 3.2 & -25.5 & -14.6 & 0.0 & -33.2 & -9.5 & -0.9 \\
\hline & & RF-T & -55.4 & -16.8 & 0.6 & -29.8 & -17.7 & -1.4 & -39.3 & -13.0 & -2.5 \\
\hline & & RF-T-S & -56.1 & -18.0 & 5.2 & -31.8 & -19.0 & -0.3 & -42.4 & -13.4 & -3.0 \\
\hline \multirow{6}{*}{$\mathrm{RCP} 8.5$} & \multirow{3}{*}{ 2050s } & $\mathrm{RF}$ & -53.3 & -13.4 & 5.2 & -29.0 & -14.0 & 1.4 & -38.1 & -9.8 & 0.0 \\
\hline & & RF-T & -56.1 & -17.7 & 2.3 & -32.9 & -19.0 & -0.3 & -44.4 & -13.0 & -2.2 \\
\hline & & RF-T-S & -56.8 & -19.0 & 7.0 & -34.5 & -20.3 & 0.9 & -46.3 & -13.9 & -2.1 \\
\hline & \multirow{3}{*}{$2080 \mathrm{~s}$} & $\mathrm{RF}$ & -56.8 & -18.6 & 8.1 & -30.2 & -16.4 & 2.3 & -49.1 & -14.4 & -0.6 \\
\hline & & RF-T & -59.4 & -23.9 & 4.3 & -40.9 & -24.9 & -0.2 & -49.8 & -18.5 & -3.1 \\
\hline & & RF-T-S & -59.9 & -25.8 & 7.8 & -42.5 & -26.7 & 2.0 & -51.0 & -20.1 & -3.7 \\
\hline
\end{tabular}

In contrast to peak flows, the extreme low flows are generally expected to decrease, regardless of the applied scenarios (Figures 10 and 11). This is probably due to a consistent decrease in rainfall during the dry season (e.g., see Figure 3 and Table 1 for detail). Further, as opposed to extreme peak flows, it is noted that more negative change (up to $60 \%$ ) in low flows is predicted in the upstream part of the watersheds where a higher groundwater contribution is expected. This could be likely related to the increase in temperature in the mountainous area as compared to the lowland part of the watersheds, which is also consistent with previous studies by Giambelluca et al. [21] regarding historical temperature data trends. Another factor could be an increase in solar radiation values during the dry season when baseflow contribution to stream is dominant. Increase in temperature and solar radiation would result in an increase in actual evapotranspiration. When this is combined with a consistent decrease in rainfall during the dry period, an overall effect would be a consistent decrease in low flows. This is projected to be more severe by the end of the 21st century, especially under the RCP 8.5 scenario (Table 5 and Figure 11). Furthermore, the RCP 8.5 scenario generally leads to a drier condition as compared to the RCP 4.5 scenario (Figures 10 and 11). This is most likely due to an overall larger decline in rainfall amount and increase in evapotranspiration during the dry season for RCP 8.5, which is also consistent with recent studies by Leta et al. [3,4] and Safeeq and Fares [41]. Leta et al. [3,4] assessed the impacts of future climate change (under A1B emission, RCP 4.5 and 8.5 scenarios) on water budget elements of Heeia and Nuuanu area watersheds on Oahu. They found that monthly baseflow values are expected to consistently decrease irrespective of the applied scenarios. Furthermore, Safeeq and Fares [41] reported an overall decrease in dry season streamflow values under the A1B emission scenario for Makaha watershed, which is also located on Oahu. The previous studies' results regarding the impacts of climate change on water budgets are generally consistent with our findings. 

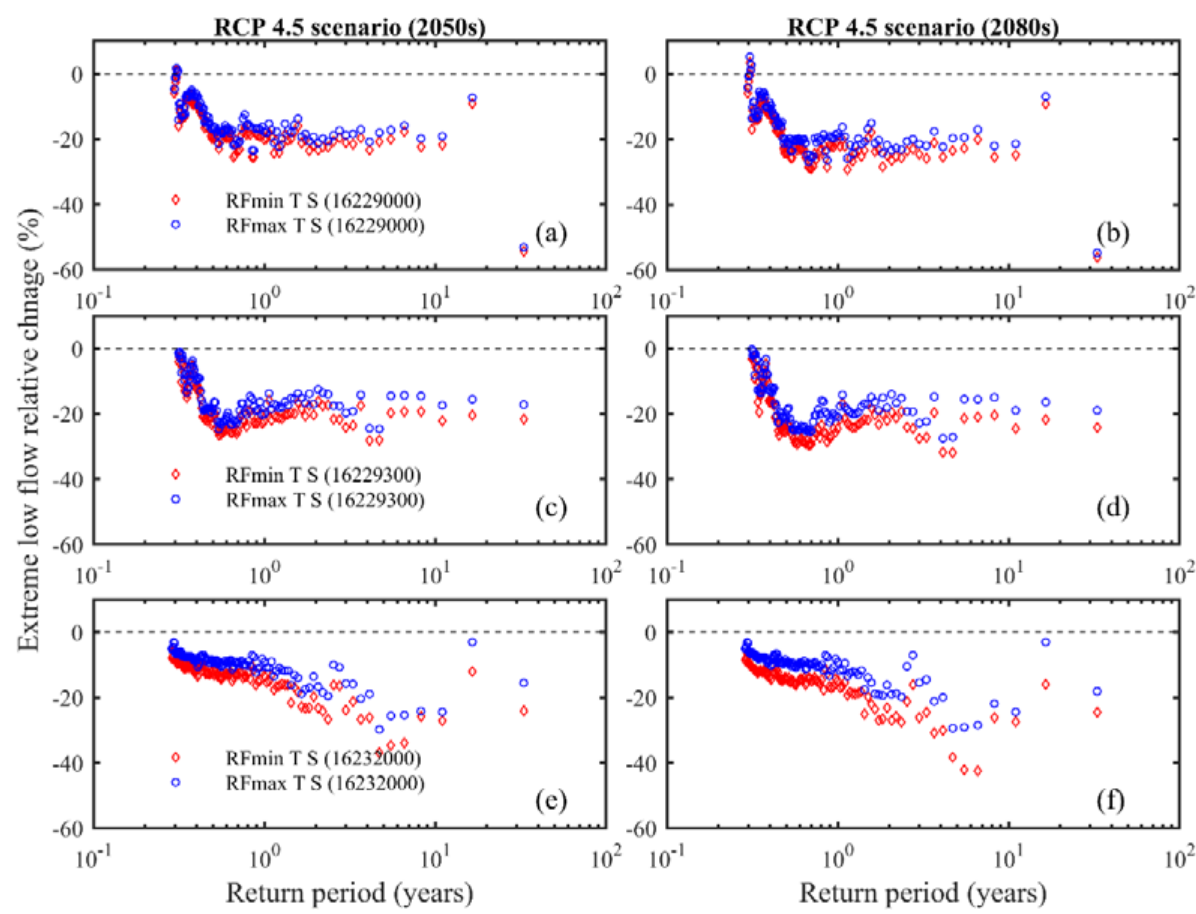

Figure 10. Relative changes in extreme low flows of Kalihi watershed (a-d) and of Nuuanu watershed (e,f) by 2050s (Left) and 2080s (Right) for the Representative Concentration Pathways (RCP) 4.5 scenario.
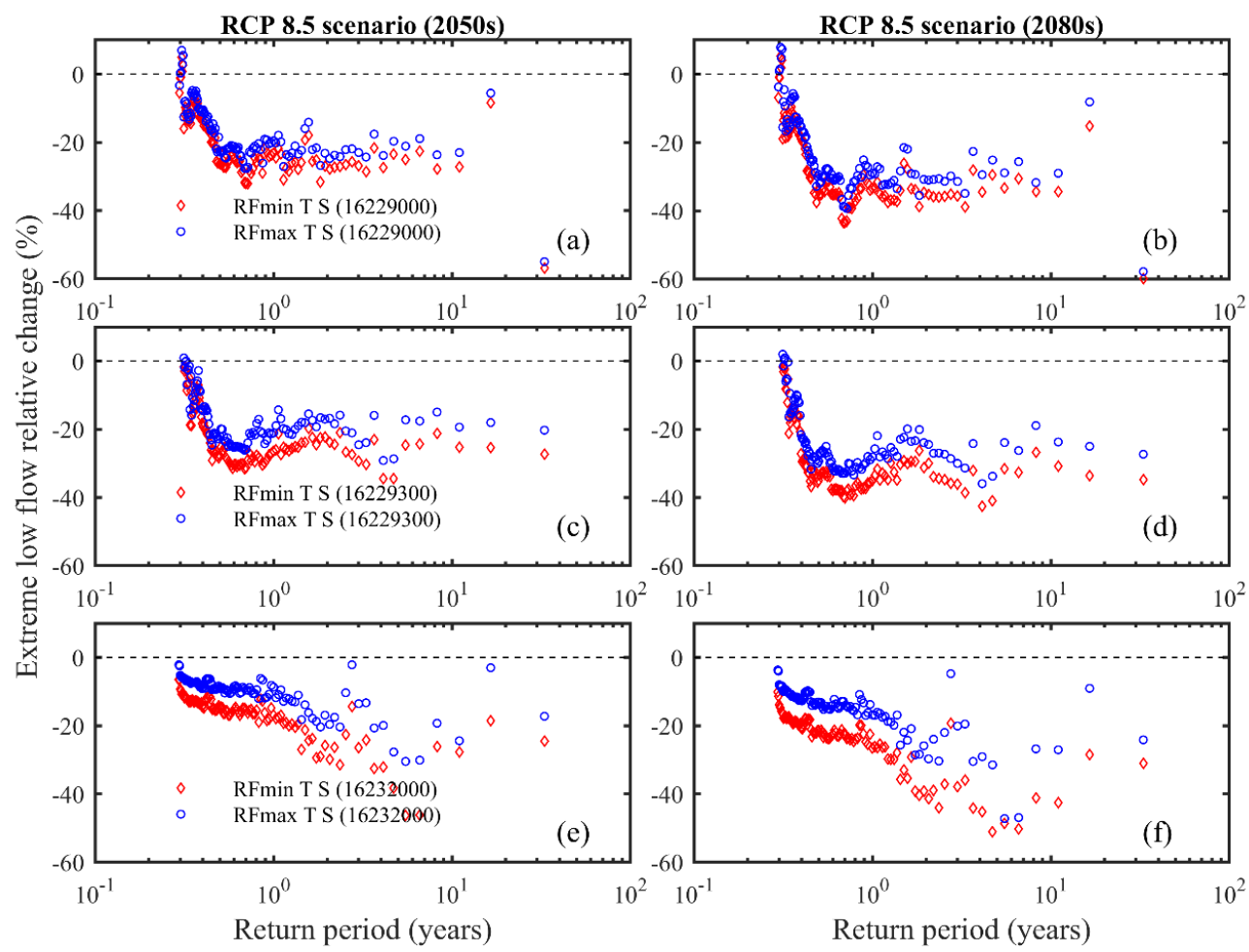

Figure 11. Relative changes in extreme low flows of Kalihi watershed at 16229000 by 2050s (a-d) and of Nuuanu watershed (e,f) by 2050s (Left) and 2080s (Right) for Representative Concentration Pathways (RCP) 8.5 scenario. 
As a consequence of climate change, the baseline low flows distributions are shifted downward for all scenarios (Figures 10 and 11). This implies that lower low flows are obtained for the same return period or the low flows that happen with certain return periods under the baseline condition will take place more frequently (smaller return periods) under all future scenarios. Hence, climate change may lead to earlier occurrence of droughts, which are expected to be more frequent as well as severe towards the end of this century. The impact of climate change is much stronger for return periods that are higher than about one year. Under the considered climate scenarios, streamflow may be too low during the dry season to fulfill the required amount of water for drinking water supply, agricultural activities, and other uses. In addition, while submarine groundwater discharge to the coastal area is expected to decrease, the chance for salt water intrusion and groundwater salinization would be very high. As the main drinking water supply for the populated Oahu is from groundwater, the groundwater resources are expected to be negatively affected in the future. Thus, climate change will likely cause water scarcity to the communities, inhabitants, and riverine ecosystems. This highlights the need to enhance efforts on groundwater management and conservation on Oahu and similar islands, including utilizing this and similar previous studies (e.g., Leta et al. [3,4]).

Finally, the significant impact of evapotranspiration on the low flows is clearly demonstrated by the larger percent of relative change (Table 5, Figures 10 and 11) due to the high sensitivity of low flows to rainfall, temperature, and solar radiation. This is more pronounced for higher return periods (extremely low flow values). Overall, while the 2050s and 2080s of both RCP 4.5 and RCP 8.5 scenarios show similar trends (Figures 10 and 11), the 2080s scenarios are predicted to cause higher changes in low flows as compared to the 2050s (Table 5). As climate is expected to negatively impact the groundwater reservoir of Oahu, this study encourages implementing water conservation measures, such as that by Leta et al. [4]. The study proposes the use of water harvesting structures to capture storm water during the wet season and then utilize the harvested water to artificially inject into sub-surface aquifer systems, thereby enhancing groundwater recharge. Such strategies maybe feasible as the wet season streamflow values (extremely peak flows) show an increase or stable conditions under climate change (see Figures 8 and 9).

\section{Conclusions}

By using available geo-spatial and hydro-meteorological data, this study set-up, calibrated, and validated the SWAT model for the Kalihi and Nuuanu watersheds of Oahu (Hawaii). The study aimed to use the model for assessing the impact of future climate change on daily streamflow duration curve, extreme peak flows (floods), and extreme low flows (droughts). The model was run with 35 years (1980-2014) of historical data, which were perturbed by using perturbation factors to reflect projected future climate condition. The perturbed future climate data includes rainfall values based on projected rainfall anomalies of the RCP 4.5 and 8.5 scenarios [18] and temperature and solar radiation values, which were based on expected changes [41,44]. In order to assess the relative sensitivity of streamflow and hydrological extremes to climate change, we formulated six climate change scenarios for the middle (2041-2070) and end (2071-2100) of the 21st century.

SWAT adequately reproduced the observed daily streamflow hydrographs and their temporal evolution at three USGS flow gauging stations as the calculated NSE values were greater than 0.5 for both calibration and validation periods. In addition, the model bracketed more than $80 \%$ of observed streamflow data at 95\% model prediction uncertainty with narrow uncertainty band, indicating the suitability of the model for future daily streamflow prediction.

Predicted climate change scenarios generally indicated an overall decline in daily streamflow values, extreme peak and low flows, and thus downward shift in the respective Flow Duration Curves (FDC). However, some extreme peak flows, which have higher return periods, are predicted to increase by as much as $22 \%$ whereas the extreme low flow values are expected to consistently decrease by as much as $60 \%$, when compared to the baseline values. More importantly, larger negative changes in extreme low flows are projected in the upstream part of the watersheds where higher groundwater 
recharge is expected. The latter expected change is probably due to more warming as a result of increase in temperature and solar radiation values, including consistent decrease in rainfall, during the dry season in the mountainous regions.

When compared to the RCP 4.5 scenario, the RCP 8.5 scenario is projected to cause increasingly severe changes on extreme peak and low flow values, especially during the later period of the 21st century. Surprisingly, both extreme negative and positive changes are predicted under the RCP 8.5 scenario. These effects may have serious implications on freshwater availability and groundwater sustainability of the Hawaiian and similar Islands. In general, our findings are consistent with previous studies on Oahu that focused on future climate change impacts on monthly and annual water budgets $[3,4,41]$.

Overall, the study's findings show that while the intensity of extreme peak flow events with high return periods is anticipated to increase, floods are less likely to become more frequent in the future, in contrast to hydrological droughts. The severity of drought is likely amplified toward the end of this century. Further, the timing of hydrological droughts occurrence is expected to occur earlier in comparison to the present hydrological conditions, suggesting a need for groundwater conservation efforts. Due to such severe consequences of climate changes, water resources managers, planners, and ecological conservationists may need to prepare appropriate mitigation measures, such as enhancing groundwater availability through artificially recharging groundwater aquifers from water captured by water harvesting structures, as proposed by Leta et al. [4]. This study can also be used as a supportive tool to help water resources managers and decision makers for evaluating the implications of climate change on streamflow and its extreme values.

Author Contributions: O.T.L. conceived of, designed, performed, analyzed, interpreted, and drafted the paper; A.I.E.-K. and H.D. supervised the research, contributed ideas during analysis and interpretation, and edited the paper.

Funding: This research was funded by the Pacific Regional Integrated Sciences and Assessments (Pacific RISA), NOAA Climate Program Office grant number NA10OAR4310216 and the Honolulu Board of Water Supply grant number C15548001.

Acknowledgments: The authors would like to thank the Pacific RISA, NOAA Climate Program Office and the Honolulu Board of Water Supply for funding this research. The views expressed herein are those of the authors and do not necessarily reflect the views of any funding agencies. This is a contributed paper WRRC-CP-2018-17 of the Water Resources Research Center (WRRC) and 10406 of the School of Ocean and Earth Science and Technology (SOEST), University of Hawaii at Manoa, Honolulu, Hawaii.

Conflicts of Interest: The authors declare no conflict of interest.

\section{References}

1. IPCC. Summary for policymakers. In Climate Change 2014: Impacts, Adaptation, and Vulnerability. Part A: Global and Sectoral Aspects. Contribution of Working Group II to the Fifth Assessment Report of the Intergovernmental Panel on Climate Change; Field, C.B., Barros, V.R., Dokken, D.J., Mach, K.J., Mastrandrea, M.D., Bilir, T.E., Chatterjee, M., Ebi, K.L., Estrada, Y.O., Genova, R.C., et al., Eds.; Cambridge University Press: Cambridge, UK; New York, NY, USA, 2014; pp. 1-32.

2. Ahiablame, L.; Sinha, T.; Paul, M.; Ji, J.-H.; Rajib, A. Streamflow response to potential land use and climate changes in the James River watershed, Upper Midwest United States. J. Hydrol. Reg. Stud. 2017, 14, 150-166. [CrossRef]

3. Leta, O.T.; El-Kadi, A.I.; Dulai, H.; Ghazal, K.A. Assessment of climate change impacts on water balance components of Heeia watershed in Hawaii. J. Hydrol. Reg. Stud. 2016, 8, 182-197. [CrossRef]

4. Leta, O.T.; El-Kadi, A.I.; Dulai, H. Implications of climate change on water budgets and reservoir water harvesting of Nuuanu area watersheds, Oahu, Hawaii. J. Water Resour. Plan. Manag. 2017, 143, 05017013. [CrossRef]

5. Shrestha, N.K.; Du, X.; Wang, J. Assessing climate change impacts on fresh water resources of the Athabasca River Basin, Canada. Sci. Total Environ. 2017, 601-602, 425-440. [CrossRef] [PubMed] 
6. Mohammed, K.; Islam, A.K.M.S.; Islam, G.M.T.; Alfieri, L.; Bala, S.K.; Khan, M.J.U. Impact of high-end climate change on floods and low flows of the Brahmaputra river. J. Hydrol. Eng. 2017, 22, 04017041. [CrossRef]

7. Bodian, A.; Dezetter, A.; Diop, L.; Deme, A.; Djaman, K.; Diop, A. Future climate change impacts on streamflows of two main West Africa river Basins: Senegal and Gambia. Hydrology 2018, 5, 21. [CrossRef]

8. Vetter, T.; Reinhardt, J.; Flörke, M.; van Griensven, A.; Hattermann, F.; Huang, S.; Koch, H.; Pechlivanidis, I.G.; Plötner, S.; Seidou, O.; et al. Evaluation of sources of uncertainty in projected hydrological changes under climate change in 12 large-scale river Basins. Clim. Chang. 2017, 141, 419-433. [CrossRef]

9. Taye, M.T.; Ntegeka, V.; Ogiramoi, N.P.; Willems, P. Assessment of climate change impact on hydrological extremes in two source regions of the Nile River Basin. Hydrol. Earth Syst. Sci. 2011, 15, 209-222. [CrossRef]

10. Mantua, N.; Tohver, I.; Hamlet, A. Climate change impacts on streamflow extremes and summertime stream temperature and their possible consequences for freshwater salmon habitat in Washington state. Clim. Chang. 2010, 102, 187-223. [CrossRef]

11. Gingerich, S.B.; Oki, D.S. Groundwater in Hawaii. U.S. Geological Survey Fact Sheet; USGS: Reston, VA, USA, 2000.

12. Pulwarty, R.S.; Nurse, L.A.; Trotz, U.O. Caribbean Islands in a changing climate. Environ. Sci. Policy Sust. Dev. 2010, 52, 16-27. [CrossRef]

13. Bassiouni, M.; Oki, D.S. Trends and shifts in streamflow in Hawaii, 1913-2008. Hydrol. Process. 2013, 27, 1484-1500. [CrossRef]

14. Oki, D.S. Trends in Streamflow Characteristics in Hawaii, 1913-2003; U.S. Geological Survey Fact Sheet; 2001-3104; USGS: Reston, VA, USA, 2004; p. 4.

15. Timm, O.; Diaz, H.F. Synoptic-statistical approach to regional downscaling of ipcc twenty-first-century climate projections: Seasonal rainfall over the Hawaiian Islands. J. Clim. 2009, 22, 4261-4280. [CrossRef]

16. Chu, P.-S.; Chen, H. Interannual and interdecadal rainfall variations in the Hawaiian Islands. J. Clim. 2005, 18, 4796-4813. [CrossRef]

17. Timm, O.E.; Diaz, H.F.; Giambelluca, T.W.; Takahashi, M. Projection of changes in the frequency of heavy rain events over Hawaii based on leading pacific climate modes. J. Geophys. Res. Atmos. 2011, 116, D04109.

18. Timm, O.E.; Giambelluca, T.W.; Diaz, H.F. Statistical downscaling of rainfall changes in Hawaii based on the CMIP5 global model projections. J. Geophys. Res. Atmos. 2015, 120. [CrossRef]

19. Engott, J.A.; Johnson, A.G.; Bassiouni, M.; Izuka, S.K. Spatially Distributed Groundwater Recharge for 2010 Land Cover Estimated Using a Water-Budget Model for the Island of Oahu, Hawaii; U.S. Geological Survey Scientific Investigations Report 2015-5010; USGS: Reston, VA, USA, 2015; p. 49.

20. Diaz, H.F.; Giambelluca, T.W.; Eischeid, J.K. Changes in the vertical profiles of mean temperature and humidity in the Hawaiian Islands. Glob. Planet. Chang. 2011, 77, 21-25. [CrossRef]

21. Giambelluca, T.W.; Diaz, H.F.; Luke, M.S.A. Secular temperature changes in Hawaii. Geophys. Res. Lett. 2008, 35, L12702. [CrossRef]

22. Finucane, M.L.; Keener, V.W. Understanding the climate-sensitive decisions and information needs of Island communities. J. Indian Ocean Reg. 2015, 11, 110-120. [CrossRef]

23. Burnett, K.; Wada, C. Optimal groundwater management when recharge is declining: A method for valuing the recharge benefits of watershed conservation. Environ. Econ. Policy Stud. 2014, 16, 263-278. [CrossRef]

24. Firing, Y.L.; Merrifield, M.A. Extreme sea level events at Hawaii: Influence of mesoscale eddies. Geophys. Res. Lett. 2004, 31, L24306. [CrossRef]

25. Firing, Y.L.; Merrifield, M.A.; Schroeder, T.A.; Qiu, B. Interdecadal sea level fluctuations at Hawaii. J. Phys. Oceanogr. 2004, 34, 2514-2524. [CrossRef]

26. Caccamise, D.J.; Merrifield, M.A.; Bevis, M.; Foster, J.; Firing, Y.L.; Schenewerk, M.S.; Taylor, F.W.; Thomas, D.A. Sea level rise at Honolulu and Hilo, Hawaii: Gps estimates of differential land motion. Geophys. Res. Lett. 2005, 32, L03607. [CrossRef]

27. Storlazzi, C.D.; Elias, E.P.L.; Berkowitz, P. Many Atolls may be uninhabitable within decades due to climate change. Sci. Rep. 2015, 5, 14546. [CrossRef] [PubMed]

28. Storlazzi, C.D.; Gingerich, S.B.; van Dongeren, A.; Cheriton, O.M.; Swarzenski, P.W.; Quataert, E.; Voss, C.I.; Field, D.W.; Annamalai, H.; Piniak, G.A.; et al. Most Atolls will be uninhabitable by the mid-21st century because of sea-level rise exacerbating wave-driven flooding. Sci. Adv. 2018, 4. [CrossRef] [PubMed] 
29. Habel, S.; Fletcher, C.H.; Rotzoll, K.; El-Kadi, A.I. Development of a model to simulate groundwater inundation induced by sea-level rise and high tides in Honolulu, Hawaii. Water Res. 2017, 114, 122-134. [CrossRef] [PubMed]

30. Rotzoll, K.; Fletcher, C.H. Assessment of groundwater inundation as a consequence of sea-level rise. Nat. Clim. Chang. 2012, 3, 477-481. [CrossRef]

31. Porter, K.; Wein, A.; Alpers, C.; Baez, A.; Barnard, P.; Carter, J.; Corsi, A.; Costner, J.; Cox, D.; Das, T.; et al. Overview of the Arkstorm Scenario; Open File Report 2010-1312; U.S. Geological Survey: Reston, VA, USA, 2011; p. 183.

32. Hawaii Community Foundation. A Blueprint for Hawaii's Water Future; Hawaii Community Foundation: Honolulu, HI, USA, 2015; p. 24.

33. Bae, D.-H.; Jung, I.-W.; Lettenmaier, D.P. Hydrologic uncertainties in climate change from IPCC AR4 GCM simulations of the Chungju Basin, Korea. J. Hydrol. 2011, 401, 90-105. [CrossRef]

34. Faramarzi, M.; Abbaspour, K.C.; Ashraf Vaghefi, S.; Farzaneh, M.R.; Zehnder, A.J.B.; Srinivasan, R.; Yang, H. Modeling impacts of climate change on freshwater availability in Africa. J. Hydrol. 2013, 480, 85-101. [CrossRef]

35. Githui, F.; Gitau, W.; Mutua, F.; Bauwens, W. Climate change impact on SWAT simulated streamflow in western Kenya. Int. J. Climatol. 2009, 29, 1823-1834. [CrossRef]

36. Jiang, T.; Chen, Y.D.; Xu, C.-y.; Chen, X.; Chen, X.; Singh, V.P. Comparison of hydrological impacts of climate change simulated by six hydrological models in the Dongjiang Basin, South China. J. Hydrol. 2007, 336, 316-333. [CrossRef]

37. Devkota, L.P.; Gyawali, D.R. Impacts of climate change on hydrological regime and water resources management of the Koshi River Basin, Nepal. J. Hydrol. Reg. Stud. 2015, 4, 502-515. [CrossRef]

38. Rahman, K.; Etienne, C.; Gago-Silva, A.; Maringanti, C.; Beniston, M.; Lehmann, A. Streamflow response to regional climate model output in the mountainous watershed: A case study from the Swiss Alps. Environ. Earth Sci. 2014, 72, 4357-4369. [CrossRef]

39. De Wit, M.J.M.; Hurk, B.; Warmerdam, P.M.M.; Torfs, P.J.J.F.; Roulin, E.; Deursen, W.P.A. Impact of climate change on low-flows in the river Meuse. Clim. Chang. 2007, 82, 351-372. [CrossRef]

40. Poelmans, L.; Van Rompaey, A.; Ntegeka, V.; Willems, P. The relative impact of climate change and urban expansion on peak flows: A case study in central Belgium. Hydrol. Process. 2011, 25, 2846-2858. [CrossRef]

41. Safeeq, M.; Fares, A. Hydrologic response of a Hawaiian watershed to future climate change scenarios. Hydrol. Process. 2012, 26, 2745-2764. [CrossRef]

42. IPCC. Climate Change 2014: Impacts, Adaptation, and Vulnerability. Part B: Regional Aspects. Contribution of Working Group II to the Fifth Assessment Report of the Intergovernmental Panel on Climate Change; Field, C.B., Barros, V.R., Dokken, D.J., Mach, K.J., Mastrandrea, M.D., Bilir, T.E., Chatterjee, M., Ebi, K.L., Estrada, Y.O., Genova, R.C., et al., Eds.; Cambridge University Press: Cambridge, UK; New York, NY, USA, 2014; p. 688.

43. Meteorology, A.B.O.; CSIRO. Climate Change in the Pacific: Scientific Assessment and New Research. Volume 1: Regional Overview. Volume 2: Country Reports; Australian Bureau of Meteorology and CSIRO; National Library of Australia: Canberra, Australia, 2011.

44. Longman, R.J.; Giambelluca, T.W.; Alliss, R.J.; Barnes, M.L. Temporal solar radiation change at high elevations in Hawaii. J. Geophys. Res. Atmos. 2014, 119, 6022-6033. [CrossRef]

45. Arnold, J.G.; Srinivasan, R.; Muttiah, R.S.; Williams, J.R. Large area hydrologic modeling and assessment part I: Model development. JAWRA J. Am. Water Resour. Assoc. 1998, 34, 73-89. [CrossRef]

46. Gassman, P.W.; Reyes, M.R.; Green, C.H.; Arnold, J.G. The soil and water assessment tool: Historical development, applications, and future research directions. Trans. ASABE 2007, 50, 1211-1250. [CrossRef]

47. Gassman, P.W.; Sadeghi, A.M.; Srinivasan, R. Applications of the SWAT model special section: Overview and insights. J. Environ. Qual. 2014, 43, 1-8. [CrossRef] [PubMed]

48. Van Liew, M.W.; Arnold, J.G.; Bosch, D.D. Problems and potential of autocalibrating a hydrologic model. Trans. ASABE 2005, 48, 1025-1040. [CrossRef]

49. Arnold, J.G.; Kiniry, J.R.; Srinivasan, R.; Williams, J.R.; Haney, E.B.; Neitsch, S.L. Soil and Water Assessment Tool; Input/Output File Documentation, Version 2009; Agrilife Blackland Research Center: Temple, TX, USA, 2011; p. 76502. 
50. Neitsch, S.L.; Arnold, J.G.; Kiniry, J.R.; Williams, J.R. Soil \& Water Assessment Tool; Theoretical Documentation, Version 2009; Grassland, Soil and Water Research Laboratory, Agricultural Rsearch Service Blackland Research Center-Texas AgriLife Research: Temple, TX, USA, 2011.

51. USDA-SCS. US Department of Agriculture-Soil Conservation Service: Urban Hydrology for Small Watersheds; USDA: Washington, DC, USA, 1986.

52. Monteith, J.L. Evaporation and environment. Symp. Soc. For. Exp. Biol. 1965, 19, 205-234.

53. Williams, J.R. Flood routing with variable travel time or variable storage coefficients. Trans. ASABE 1969, 12, 100-103. [CrossRef]

54. Abbaspour, K.C.; Yang, J.; Maximov, I.; Siber, R.; Bogner, K.; Mieleitner, J.; Zobrist, J.; Srinivasan, R. Modelling hydrology and water quality in the pre-alpine/alpine Thur watershed using SWAT. J. Hydrol. 2007, 333, 413-430. [CrossRef]

55. Van Griensven, A.; Meixner, T.; Grunwald, S.; Bishop, T.; Di Lluzio, M.; Srinivasan, R. A global sensitivity analysis tool for the parameters of multi-variable catchment models. J. Hydrol. 2006, 324, 10-23. [CrossRef]

56. Moriasi, D.N.; Arnold, J.G.; Van Liew, M.W.; Bingner, R.L.; Harmel, R.D.; Veith, T.L. Model evaluation guidelines for systematic quantification of accuracy in watershed simulations. Trans. ASABE 2007, 50, 885-900. [CrossRef]

57. Bennett, N.D.; Croke, B.F.W.; Guariso, G.; Guillaume, J.H.A.; Hamilton, S.H.; Jakeman, A.J.; Marsili-Libelli, S.; Newham, L.T.H.; Norton, J.P.; Perrin, C.; et al. Characterising performance of environmental models. Environ. Model. Softw. 2013, 40,1-20. [CrossRef]

58. Moriasi, D.; Gitau, M.; Pai, N.; Daggupati, P. Hydrologic and water quality models: Performance measures and evaluation criteria. Trans. ASABE 2015, 58, 1763-1785.

59. Nash, J.E.; Sutcliffe, J.V. River flow forecasting through conceptual models part I-A discussion of principles. J. Hydrol. 1970, 10, 282-290. [CrossRef]

60. Krause, P.; Boyle, D.P.; Bäse, F. Comparison of different efficiency criteria for hydrological model assessment. Adv. Geosci. 2005, 5, 89-97. [CrossRef]

61. Yang, J.; Reichert, P.; Abbaspour, K.C.; Xia, J.; Yang, H. Comparing uncertainty analysis techniques for a SWAT application to the Chaohe Basin in China. J. Hydrol. 2008, 358, 1-23. [CrossRef]

62. Elsner, M.; Cuo, L.; Voisin, N.; Deems, J.; Hamlet, A.; Vano, J.; Mickelson, K.B.; Lee, S.-Y.; Lettenmaier, D. Implications of 21st century climate change for the hydrology of Washington state. Clim. Chang. 2010, 102, 225-260. [CrossRef]

63. Salathe, E.P.; Mote, P.W.; Wiley, M.W. Review of scenario selection and downscaling methods for the assessment of climate change impacts on hydrology in the United States Pacific Northwest. Int. J. Climatol. 2007, 27, 1611-1621. [CrossRef]

64. Willems, P. A time series tool to support the multi-criteria performance evaluation of rainfall-runoff models. Environ. Model. Softw. 2009, 24, 311-321. [CrossRef]

65. Giambelluca, T.W.; Shuai, X.; Barnes, M.L.; Alliss, R.J.; Longman, R.J.; Miura, T.; Chen, Q.; Frazier, A.G.; Mudd, R.G.; Cuo, L.; et al. Evapotranspiration of Hawaii; University of Hawaii at Manoa: Honolulu, HI, USA, 2014; p. 131.

66. Giambelluca, T.W.; Martin, R.E.; Asner, G.P.; Huang, M.; Mudd, R.G.; Nullet, M.A.; DeLay, J.K.; Foote, D. Evapotranspiration and energy balance of native wet montane cloud forest in Hawaii. Agric. For. Meteorol. 2009, 149, 230-243. [CrossRef]

67. Abbaspour, K.C.; Rouholahnejad, E.; Vaghefi, S.; Srinivasan, R.; Yang, H.; Kløve, B. A continental-scale hydrology and water quality model for Europe: Calibration and uncertainty of a high-resolution large-scale SWAT model. J. Hydrol. 2015, 524, 733-752. [CrossRef]

68. Wolanski, E.; De'ath, G. Predicting the impact of present and future human land-use on the great barrier reef. Estuar. Coast. Shelf Sci. 2005, 64, 504-508. [CrossRef]

(C) 2018 by the authors. Licensee MDPI, Basel, Switzerland. This article is an open access article distributed under the terms and conditions of the Creative Commons Attribution (CC BY) license (http:/ / creativecommons.org/licenses/by/4.0/). 